البصيرة: مجلة الاراسات الإسلامية

AL-BASHIRAH: JOURNAL OF ISLAMIC STUDIES

Vol. 2 No. 2 (2020): 262-282

ISSN: $2807-2170$

Website: https://journal.stiba.ac.id

C)

مجلة الصراهات الإصلامية

AL-BASHIRAH

\title{
قاعدة الأصل بقاء ما كان على ما كان وتطبيقها في الصائم الذي أفطر قبل غروب الثمس خطاً: دراسة مقارنة بين المذاهب الأربعة وشيخ الإسلام ابن تيمية
}

\author{
شندري \\ المعهد العالى للدرسات الإسلامية و اللغة العربية بمكسر

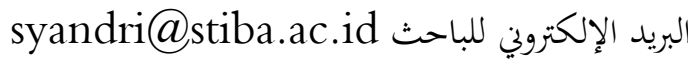 \\ محمد إحسان \\ المعهد العالى للدرسات الإسلامية و اللغة العربية بمكسر \\ البريد الإلكتروني للباحث muhikhsan@stiba.ac.id \\ أبي هندري \\ المعهد العالى للدرسات الإسلامية و اللغة العربية بمكسر
}

abihendribinrosulung@gmail.com البريد الإكتروين للباحث

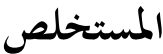

هذا البحث الذي تقدم به الباحثون بين يدي القارئ الكريم مضمونه تحدث عن حكم الصوم فيمن أفطر ظنا غروب

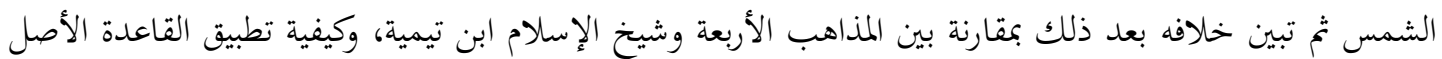

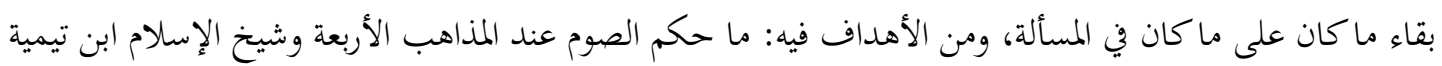

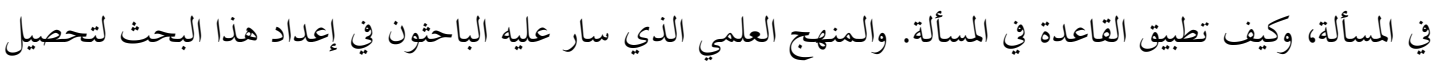
الحاصل من تلك المسائل المذكورة كالتالي: الاستقراءي والاستنباطي. وأهم النتائج المثمرة من هذا البحث المتواضع: أولاً، معرفة أدلة العلماء في من أفطر ظنا غروب الشمس ثم تبين خلافه بعد ذلك وكيفة استنباطهم بها. ثانياً، معرفة الراجح في اختلاف العلماء في المسألة.

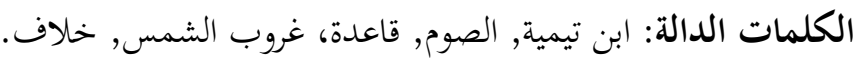




\begin{abstract}
البصيرة: مجلة الاراسات الإسلامية
AL-BASHIRAH: JOURNAL OF ISLAMIC STUDIES

Vol. 2 No. 2 (2020): 262-282

ISSN: $2807-2170$

Website: https://journal.stiba.ac.id

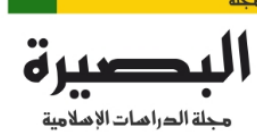

AL-BASHIRAH

JOURNAL OF ISLAMIC STUDIES

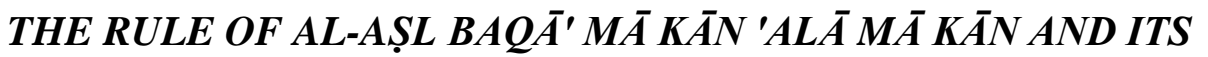

IMPLEMENTATION ON THE FALLACY OF THE ȘA'IM THAT BREAKS

THE FASTING BEFORE SUNSET: COMPARATIVE STUDY BETWEEN THE FOUR SCHOOLS AND SHAYKH AL-ISLĀM IBN TAIMIYYAH
\end{abstract}

\author{
Syandri \\ Sekolah Tinggi Ilmu Islam dan Bahasa Arab (STIBA) Makassar, Indonesia \\ Email: syandri@stiba.ac.id \\ Muhammad Ikhsan \\ Sekolah Tinggi Ilmu Islam dan Bahasa Arab (STIBA) Makassar, Indonesia \\ Email: muhikhsan@stiba.ac.id

\begin{abstract}
Abi Hendri
Sekolah Tinggi Ilmu Islam dan Bahasa Arab (STIBA) Makassar, Indonesia

Email: abihendribinrosulung@gmail.com
\end{abstract}

\begin{abstract}
This research discusses the law of the people who break the fast assuming the sun has set, then proved afterwards that the sun has not set by comparing the four schools and Shaykh al-Islām Ibn Taymiyyah, as well as how the implementation of the rule al-Aṣl Baqā' mā Kān 'alā mā Kān. This research aims to find out how the law of fasting according to the four schools, Shaykh Islam Ibn Taymiyyah in this matter, and how the above rules are implemented in this matter. The scientific method used in this study is inductive and deductive methods. The results showed that the law of fasting according to jumhür al-ulamà' for people who break the fast assuming the sun has set, then it is clear afterwards that the sun has not set is the unvalid fast, and he is obliged to replace (qad̄') it based on the proposition in their view. Jumhür put this issue in the rule of al-așl baqā' mā kān 'alā mā kān. In contrast to Shaykh al-Islām Ibn Taimiyah who considers that his fasting is valid and unnecessary based on the proposition on which he handles it, and he does not include this problem in the rule of al-aṣl baqā' mā kān 'alā mā kān.
\end{abstract}

Keywords: Ibn Taymiyyah, fasting, rules, sunset, ikhtilaf. 
فإن دين الإسلام هو دين شامل كامل متكامل ما من مسألة إلا وقد بينها بالقرآن والسنة، قال

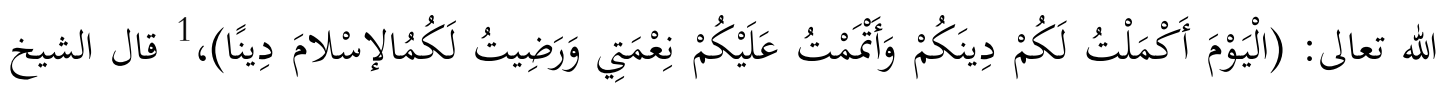
السعدي في تفسيره عن قوله تعالى (اليوم أكملت لكم دينكم) بتمام النصر وتكميل الشرائع الظاهرة

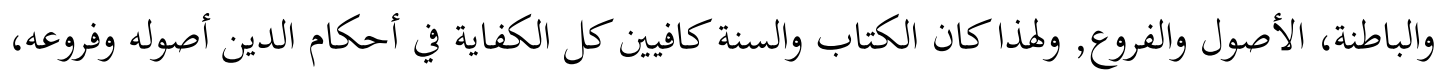

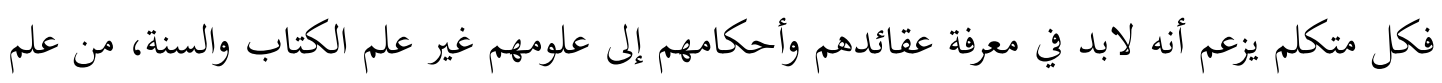

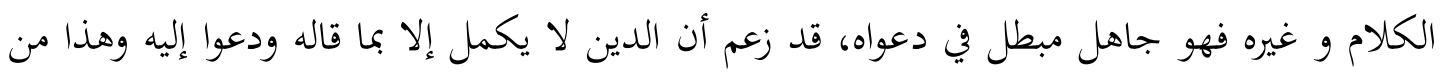

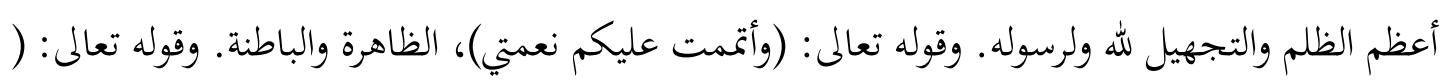

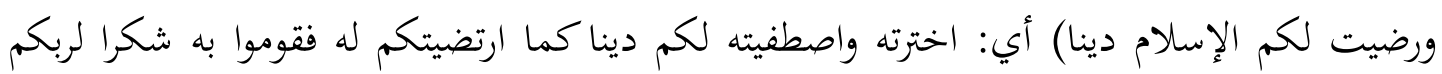
واحمدوا الذي منّ عليكم بأفضل الأديان وأشرفها وأكملها. 2

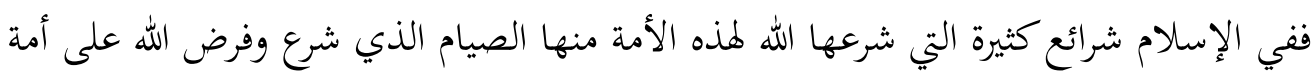

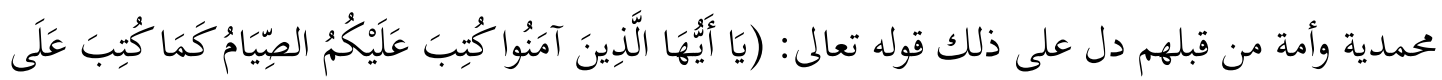

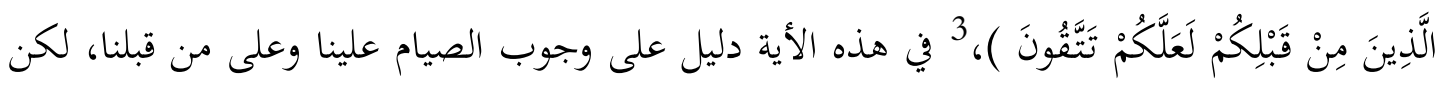

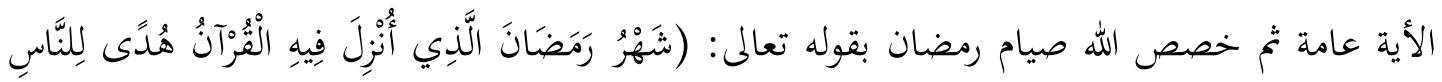

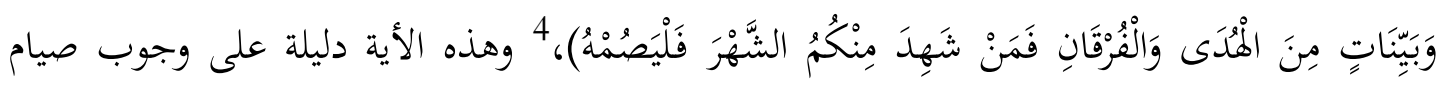

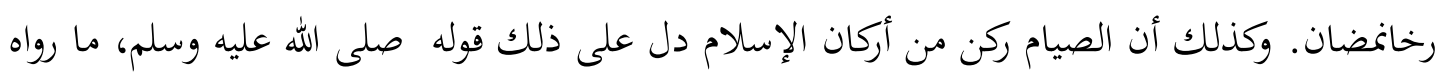

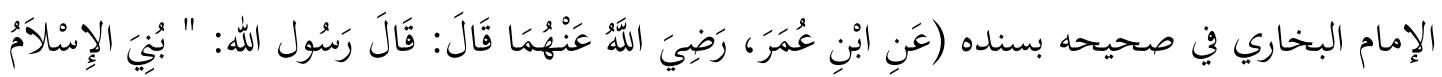

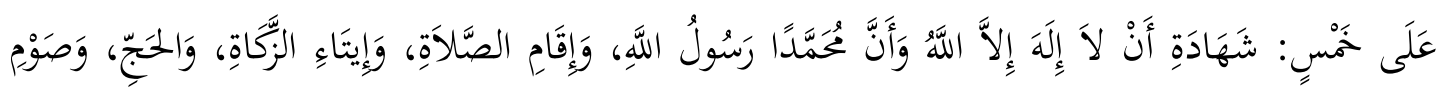

1 سورة المائدة: الأية 3

2أبو عبد الرممن بن ناصر بن عبد الله بن ناصر آل سعدي، الجزء الأول (الطبعة الثانية،ييروت - لبنان؛

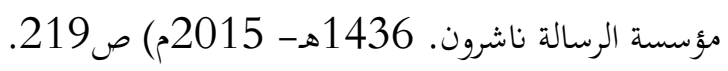
3وسرة البقرة: الأية 183

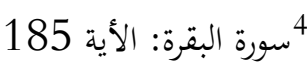


البصيرة: مجلة الاراسات الإسلامية

AL-BASHIRAH: JOURNAL OF ISLAMIC STUDIES

Vol. 2 No. 2 (2020): 262-282

ISSN: $2807-2170$

Website: https://journal.stiba.ac.id

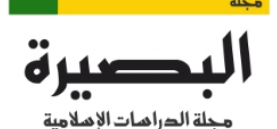

مجلة الصراهات الإصلامية

AL-BASHIRAH

رَمَضَانَ )، 5 قال الشيخ العثيمين في شرح الأربعين النووية عن هذا الحديث: فتنوعت هذه الدعائم الخمس على هذه الوجوه تكميلا للامتحان، لأن بعض الناس يسهل عليه أن يصوم، ولكن لا يسهل عليه أن يبذل قرشا واحدا، وبعض الناس يسهل عليه أن يصلي، ولكن يصعب عليه أن يصوم. 6

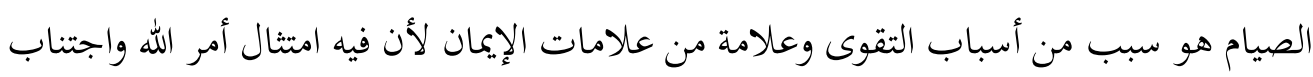
هيه، حينما يصوم الصائم فترك ما فاه الله محا يبطل الصيام من الأكل والشرب والجماع، وترك مع المحاولة

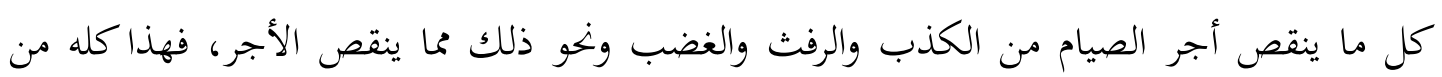
التقوى والإيمان، ومن حكمة الصيام التسوية بين الأغنياء والمساكين، بين الأقوياء والضعفاء حين يصومون، فهم سواء.

الصيام حق من حقوق الله على الأمة الإسلامية الذي لابد منه حفظه واهتمام به وأدائه حق الأداء من الأحكام المتعلقة به، كشروطه، وأركانه، وسننه، ومبطلاته. رونعلم أن في أداء الصيام مسائل قد لا يعرفها بعض الناس ثم وقع فيها، منها الأكل الذي بُني على الشك والتوهم على غروب الشمس، إذا كان بُني على ذلك ثم تبين بعد ذلك خلافها فحينئذ صيامه باطل وعليه القضاء للقاعدة: (الأصل

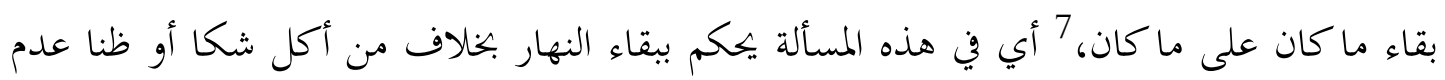
طلوع الشمس فحينئ صيامه صحيح إن تبين بعد ذلك خلافه فعليه استمرار الصيام لأنه يحكم ببقاء الليل. وكذلك لمن أكل بالتوهم فلا يهكم به أي لا يصح صيامه إن تبين أن الشمس لم تغرب للقاعدة (لا عبرة بالتوهم) 8. وأما الأكل الذي بُني على السبب وعلى الظن على غروب الشمس ثم تبين خلافه بعد ذلك ففي هذه المسألة اختلف العلماء على قولين، بعضهم قال على بطلان الصيام فعليه قضاء منهم الأئمة الأربعة بالأدلة التي استدلوا بها وبالقاعدة (الأصل بقاء ما كان على ما كان) وهذا الرأي ذهب

5 5 الله محمد بن إسماعيل بن إبراهيم بن بردزبه البخاري الجعفي الجزء التاسع(الطبعة: الأولى، دار طوق

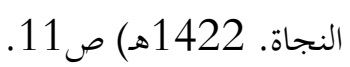

6ممد بن صالح بن محمد العثيمين، شرح الأربعين النبوية، الجزء الأول(الطبعة الأولى، الأزهر ـ القاهرة ـ جمهورية

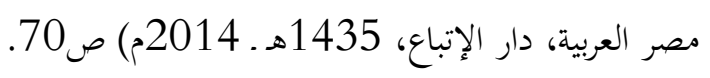

7مسلم بن محمد بن ماجد الدوسرى، الممتع في القوادعد الفقهية، الجزء الأول (الطبعة الأولى، الرياض ـ المملكة

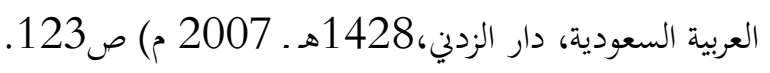

8هسلم بن محمد بن ماجد الدوسرى، الممتع في القوادعد الفقهية، الجزء الأول ص151. 
البصيرة: مجلة الاراسات الإسلامية

AL-BASHIRAH: JOURNAL OF ISLAMIC STUDIES

Vol. 2 No. 2 (2020): 262-282

ISSN: $2807-2170$

Website: https://journal.stiba.ac.id

البصيرة

مجلة الصراهات الإصلامية

AL-BASHIRAH

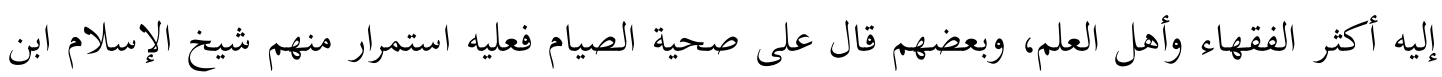

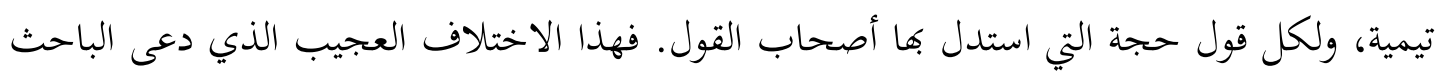

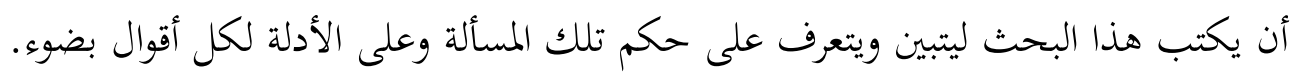

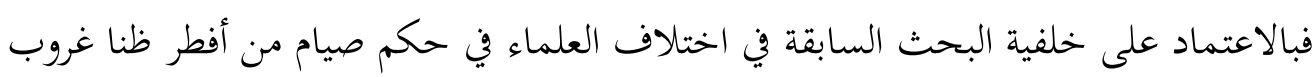
الشمس إذا تبين بعد ذلك خلافه، تعينت أسئلة البحث بما يلي:

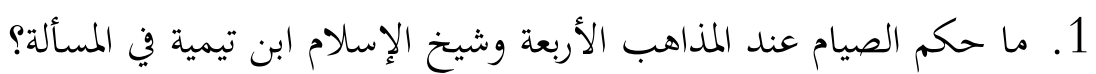

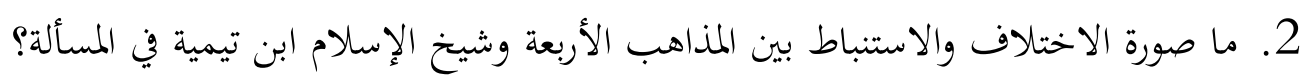
3. كيف تطبيق القاعدة في المسألة؟ ومما سبق, كان ما استهدف الباحثون من هذا البحث فيما يلي:

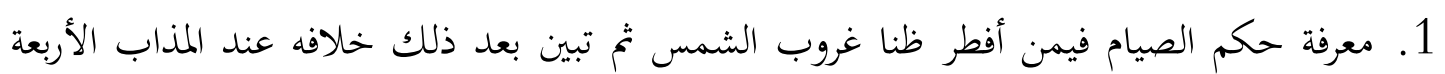
وسيخ الإسلام ابن تيمية في المسألة. 2. معرفة أدلة كل أصحاب الأقوال وكيفية استنباطهم منها ومعرفة صورة الاختلاف وسبابه في المسألة. 3. التعرف على كيفية تطبيق قاعدة بقاء ما كان على ماكان في المسألة.

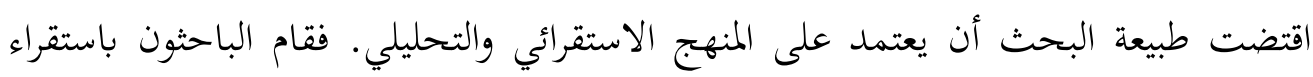

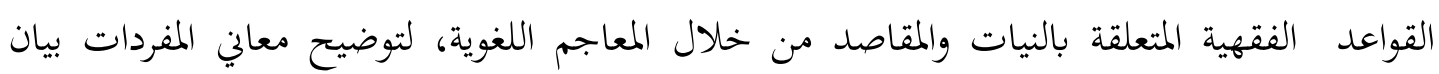

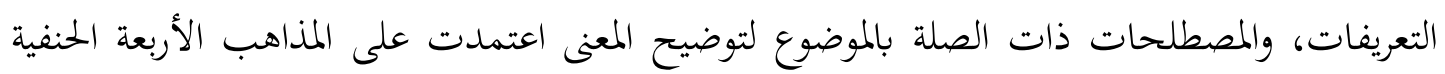

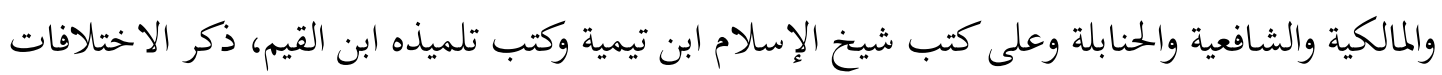

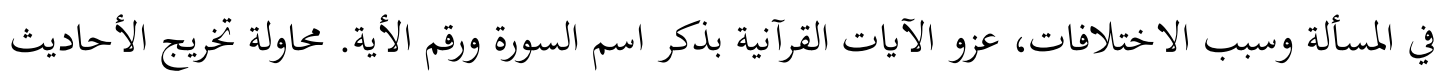
النبوية، والآثار، من المصادر الأصلية قدر الإمكان.

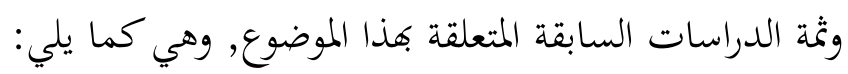

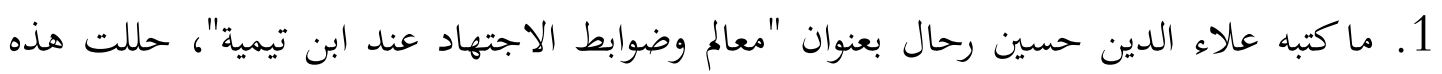

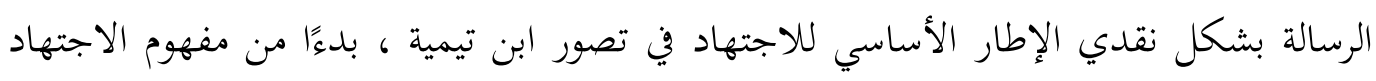

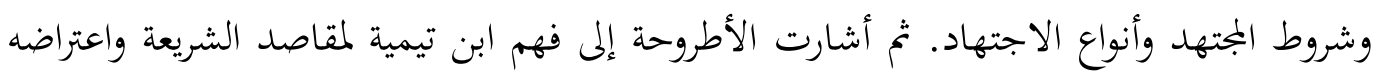


البصيرة: مجلة الاراسات الإسلامية

AL-BASHIRAH: JOURNAL OF ISLAMIC STUDIES

Vol. 2 No. 2 (2020): 262-282

ISSN: $2807-2170$

Website: https://journal.stiba.ac.id

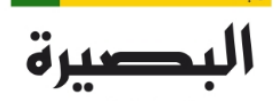

مجلة الصراهات الإصلامية

AL-BASHIRAH

على حصر أحكام الخمسة في شرعية معروفة فقط. ناقشت الدراسة الممارسة الفقهية لابن تيمية في معالجة القضايا المعاصرة المتعلقة بحياة الناس. 9

2. ما كتبه نور عيني نوفيرا, أندي إندرا فوتري وبختيار بحري مفوليانج في بجلة البصيرة للدراسات الإسلامية بعنوان "أحكام صيام المسنين" (دراسة فقهية مقارنة). 10

البحث

\section{معنى الصوم لغة والاصطلاحا.}

فمعنى الصوم في اللغة هو: ترك الأكل والكالام. وقوله عز وجل: (إِّنِ نَذَرْتُ لِلرَّمَنِ صَوْمًا) 11

أي صمتا. ورجل صائم، وقوم وصوم، ونساء صوم وصيامى، وامرأة صومى. والصوم: قيام بلا عمل. صام الفرس على آريه: إذا لم يعتلف. ومصام الفرس: موقفه: وصامت الريح: ركدت، والماء: سكن، والشمس:

استوت في منتصف النهار. 12

أما معنى الصوم في الاصطلاح فعدة معان التي عرفها العلماء منها: عند مذهب الحنفية الصوم

هو: الإمساك عن المفطرات الثلاثة فاراً مع النية. 13 عند مذهب الماكية الصوم هو: عبارة عن إمساك خصوص في زمن خصوص على وجه مخصوص. 14ند مذهب الشافعية الصوم هو: إمساك عن المفطر

9 علاء الدين حسين رحال، معالم وضوابط الاجتهاد عند /بن تيمية، (ماليزا: الجامعة الأسلانية العالمية.

10.نور عيني نوفيرا، أحكام صيام المسنين (دراسة فقهية مقارنة) )ماكسر: المجلة الدرسات الإسلامية لبصيرة:

$$
\text { عدد } 2 \text { رقم } 2 \text { (2021) 85-106 نوفيرام احسئ }
$$

$$
\text { 11 سورة مريم: الأية } 26 .
$$

12 إسماعيل بن عباد بن العباس، أبو القاسم الطالقاني، المشهور بالصاحب بن عباد، المخيط في اللغة، الجزء

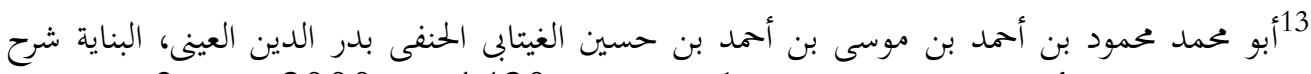

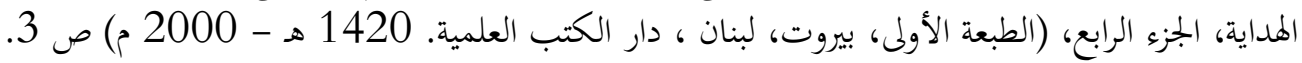

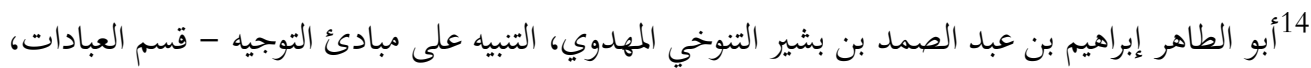

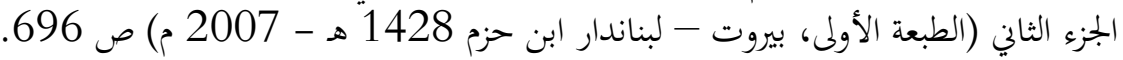




\section{البصيرة: مجلة الاراسات الإسلامية \\ AL-BASHIRAH: JOURNAL OF ISLAMIC STUDIES \\ Vol. 2 No. 2 (2020): 262-282 \\ ISSN: $2807-2170$ \\ Website: https://journal.stiba.ac.id

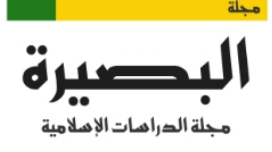 \\ AL-BASHIRAH

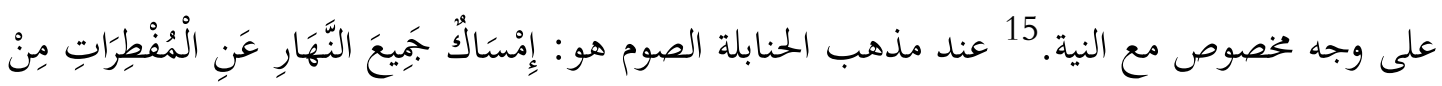

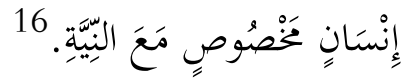

فهذه الإختلافات التي اختلف فيها علماء المذاهب الأربعة هي اختلاف في الألفاظ لا في المعنى، أما معناه فهو واحد لأن اختلاف الألفاظ في هذا لا يتأثر في المعنى، وأحسن التعريف وأكمله ما قاله الإمام محمد ابن إسماعيل الأمير اليمني الصنعاني رحمه الله: الصوم هو إمساك مخصوص وهو الإمساك عن الأكل والشرب والجماع وغيرهما مما ورد به الشرع في النهار على الوجه المشروع ويتبع ذلك الإمساك عن اللغو والرفث وغيرهما من الكلام المحرم والمكروه لورود الأحاديث بالنهي عنها في الصوم زيادة على غيره

$$
\text { في وقت مخصوص بشروط خخصوصة }
$$

أدلة مشرعية الصوم فهو من الكتاب، والسنة، والإجماع. وأما من الكتاب فهو قوله تعلى (يَأَيَّهَا

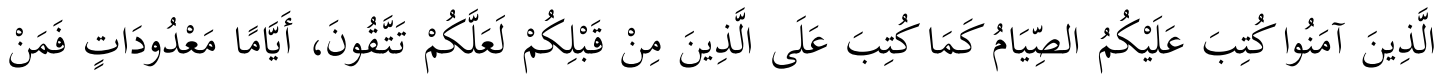

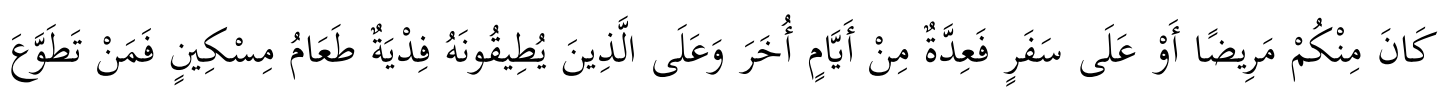

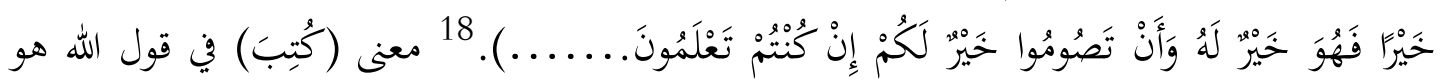

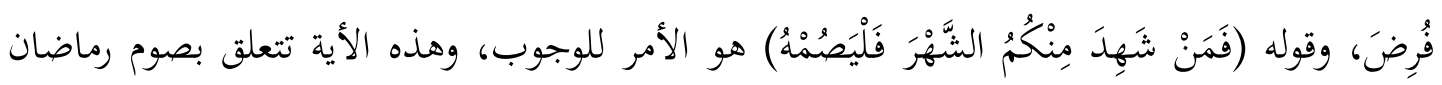
ومشرعيته. والأدلة من السنة قول النبي صلى الله عليه وسلم، ما رواه الإمام البخاري في صحيحه بسنده

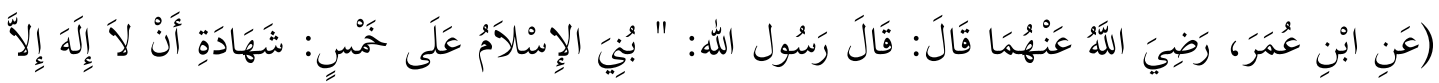

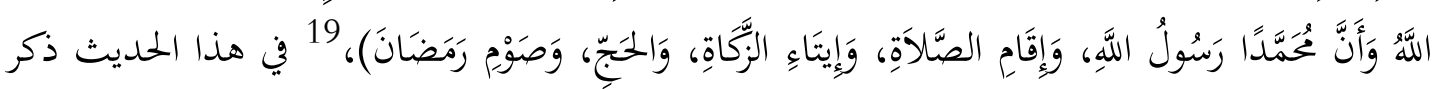

15 شمس الدين، محمد بن أحمد الخطيب الشربيني الشافعي، الإقناع في حل ألفاظ أبي شجاع، الجزء الأول ( دون الطبعة، بيروت - دار الفكر ) ص صدمب الحد 234.

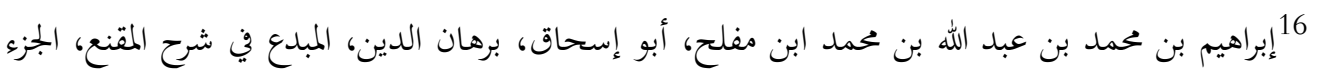

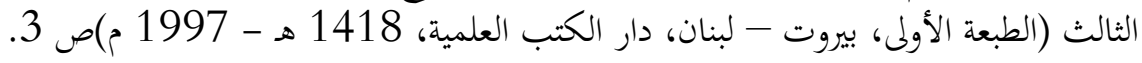

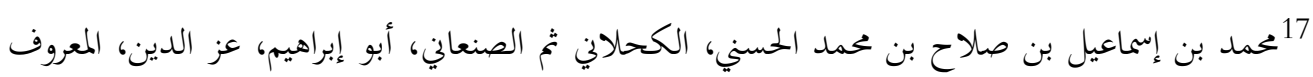

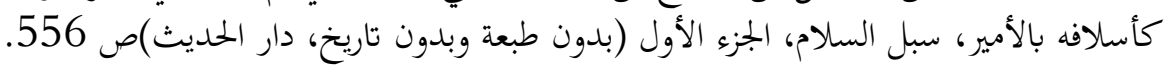

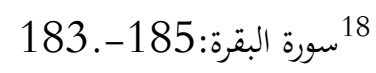

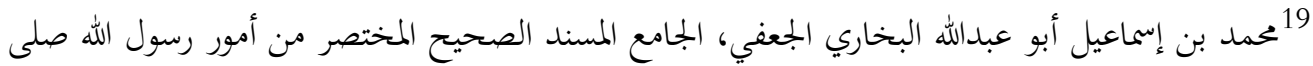

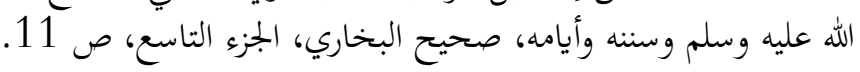




\section{البصيرة: مجلة الاراسات الإسلامية \\ AL-BASHIRAH: JOURNAL OF ISLAMIC STUDIES \\ Vol. 2 No. 2 (2020): 262-282 \\ ISSN: $2807-2170$ \\ Website: https://journal.stiba.ac.id \\ | \\ مجلة الدراهات الإصلامية \\ AL-BASHIRAH}

النبي صلى عليه وسلم أركان الإسلام ومنها صوم رمضان، والأحاديث في الدلالة على مشرعيته وفضله كثيرة مشهورة ولكن الباحث ذكر حديثاً واحداً هنا للاختصار. الصوم ينقسم إلى أربعة أقسام فالقسم الأول فهو الصوم الواجب والأخر الصوم المندوب إليه،

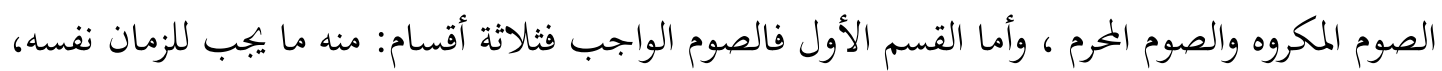
(وهو صوم شهر رمضان بعينه)، ومنه ما يجب لعلة (وهو صيام الكفارات)، ومنه ما يجب بإيجاب الإنسان ذلك على نفسه (وهو صيام النذر). وأما القسم الثاني فهو الصوم المندوب. شروط الصوم، تنقسم شروط الصوم بشكل عام إلى قسمين، أحدها شروط الوجوب وثانيهما شروط

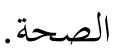

أولاً: شروط الوجوب منها:الإسلام: فلا يجب الصوم على الكافر ولو كان مرتداً كما لا يصح منه. العقل: فلا يجب الصوم على المجنون ولا يصح منه. البلوغ: فلا يجب الصوم على صبي لم يبلغ، لكن يجب على وليه أمره به إذا أطاقه ويجب أن يضربه إذا امتنع. الإطاقة: ويقصد بذلك القدرة على الصوم بلا مشقة، فلا يجب الصوم على الشيخ الكبير الذي يجههده الصوم، ولا على المريض الذي لا يرجى برؤه. ثانياً: شروط الصحة منها: الإسلام: كما تقدم. العقل: فلا يصح الصوم من غير العاقل، فلو نوى الصوم ليلاً ثم أُغمي عليه أو جن جميع النهار فلا يصح صومه ما لم يفق فيه ولو لحظة من إغمائه أو جنونه. ويجب القضاء في حالة الإغماء، أما في حالة الجنون فلا قضاء عليه. ولا يضر النوم ولو استغرق جميع النهار ويبقى صومه صحيحاً:التمييز. انقطاع دم الحيض والنفاس،النية20 أركان الصوم، تنقسم أركان الصوم إلى ثلاثة أركان منها: الإمساك عن المفطرات، الصائم، لزمان 21

\section{معنى القواعد الفقهية لغة واصطلاحا}

أما القواعد في اللغة فجمع قاعدة، وهي على وزن فاعله من قعد، والقعود يضاهي الجلوس وهو ضد القيام. وبعض أهل اللغة يفرقون بين الجلوس والقعود، من حيث أن القعون يكون من القيام، والجلوس من الضجعة والنوم ومن السجود. لهذا يقال: قواعد البيت، ولا يقال: جوالسه ويقال أيضا فلان جليس الملك، ولا يقال قعيده، ويقال أيضا لمن كان قائما: اقعد، ولمن كان نائما أو ساجدا:

20 الحاجّة سعاد زرزور، فقه العبادات على المذهب الحنبلي، الجزء الأول، ص 393-392

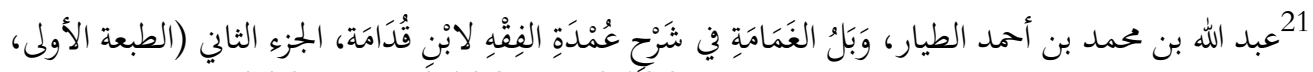

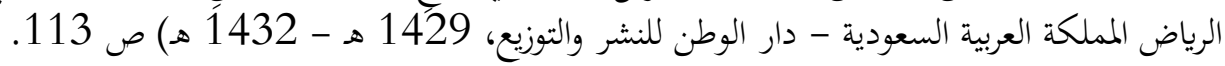




\section{البصيرة: مجلة الار اسنات الإسلامية \\ AL-BASHIRAH: JOURNAL OF ISLAMIC STUDIES \\ Vol. 2 No. 2 (2020): 262-282 \\ ISSN: $2807-2170$ \\ Website: https://journal.stiba.ac.id \\ •011 \\ مجلة الصراهات الإهلامية \\ AL-BASHIRAH

اجلس. وعلله البعض بأن القعود انتقال من علو إلى سفل ولذذا قيل لمن أصيب رجله: قعد، والجلوس: انتقال من سفل إلى علو ومنه سميت نجد جلسا لارتفاعها.

والقادة تطلق إلى عدة معان، منها:

1. البناء أصل أساسه، والجميع القواعد، يقال: فلان يبني على غير قاعدة: أي على غير أساس، قال 23.

قال الزجاج: القواعد واحدتها قاعدة وهي كالأساس والأس للبنيان. 24

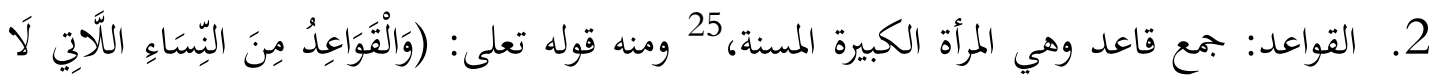
يَرْجُونَ نِكَاحًا).

أما معنى القاعدة في الاصطلاح فعرفها بعض العلماء بما يلي: 1. الأمر الكلي الذي ينطبق عليه جزئيات كثيرة يفهم أحكامها منها. 27 2. قضية كلية من حيث اشتمالها بالقوة على أحكام جزئيات موضوعها. 28 3. هي القضايا الكلية التي تعرف بالنظر فيها قضايا جزئية. 29

22 أيوب بن موسى الحسيني القريمى الكفوي أبو البقاء الحنفي، الكليات معجم في المصطلحات والفروق اللغوية

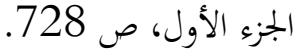

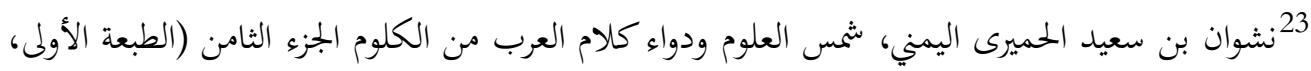
بيروت - لبنان؛ دار الفكر المعاصر. 1420هـ - 1420 1999م) ص 5566. إبراهيم بن السري بن سهل، أبو إسحاق الزجاج، معاني القرآن وإعرابه، الجزء الأول (الطبعة الأولى، بيروت

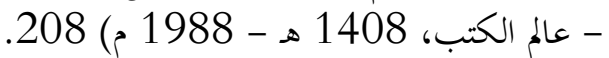
25 25مد بن مكرم بن على، أبو الفضل، جمال الدين ابن منظور الأنصاري الرويفعى الإفريقى، لسان العرب،

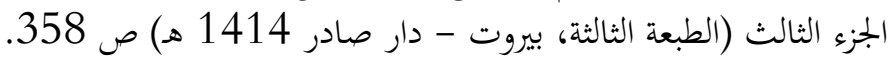

$$
\text { 26 سورة النور: } 61 .
$$

التاج الدين عبد الوهاب بن تقي الدين السبكي، الأشباه والنظائر، الجزء الأول (الطبعة الأولى، دار الكتب

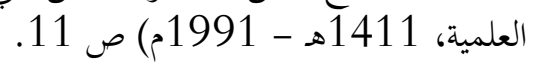

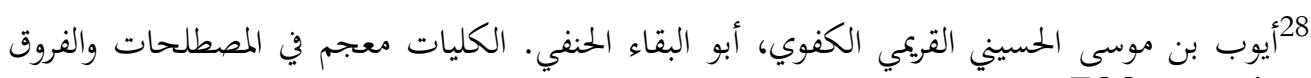
اللغوية الجزء الأول، ص 728.

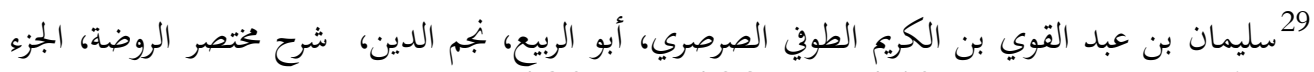

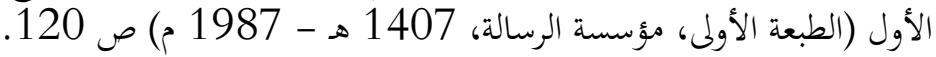


البصيرة: مجلة الاراسات الإسلامية

AL-BASHIRAH: JOURNAL OF ISLAMIC STUDIES

Vol. 2 No. 2 (2020): 262-282

ISSN: $2807-2170$

Website: https://journal.stiba.ac.id

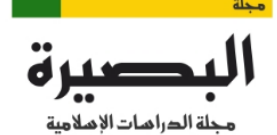

مجلة الصراهات الإهلامية

AL-BASHIRAH

4. هي قضية كلية منطبقة على جميع جزئياتا. 30

فهذه التعريفات كلها تختلف في عبارتها ولفظها ولكن تشير الى معنا واحد وهي حكم كلي أو

قضية كلية تفهم منها أحكام جزئيات التي تندرج تحت موضوعها وتطبيقها عليها. ولكن عرف بعض الفقهاء بأن القاعدة حكم أعلبي ليس كليا. كما هو المذكور في تذهيب الفروق: ومعلوم أن أكثر قواعد الفقه أغلبية.

وأما الفقهية فهي نسبة إلى الفقه وهي في اللغة العلم بالشيء والفهم له. 32 وفي الاصطلاح هو

العلم بالأحكام الشرعية العملية المكتسبة من أدللتها التفصيلية. 33

تنقسم القواعد الفقهية من حيث الشمول والاتساع إلى ثلاثة أقسام:

أ. القواعد الكلية الكبرى وهي القواعد ذوات الشمول والعام، وهي القواعد الداخلة في جميع أبواب

الفقه أو غالبها، وهي القواعد الستة وهي:

1 1 ماعدة الأمور بمقاصدها.

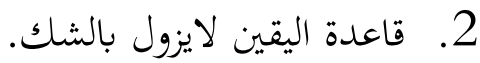

3. ق قاعدة المشقة بتحلب التيسير.

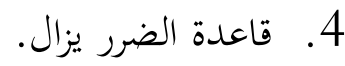

5. ـاعدة العادة محكمة.

6. قاعدة إهمال الكاملام أولى من إهمالها.

ب. القواعد الصغرى هي القواعد غير الكبرى وأضيق مجالا منها وإن كانت ذوات الشمول، وهي نوعان: 1. القواعد الداخلة في أبواب فقهية كثيرة مع عدم اختصاصها بباب فقهي معين، ولكن أقل شمولا واتساعا من القواعد الكبرى.

30علي بن محمد بن علي الزين الشريف الجرجاني، كتاب التعريفات، الجزء الأول (الطبعة الأولى، لبنان - دار

الكتب العلمية بيروت، 1403هـ - -1983مني الكين الثريف ص الجرجاي، 171.

31أبو العباس شهاب الدين أحمد بن إدريس بن عبد الرحمن المالكي الشهير بالقرافي، الفروق = أنوار البروق

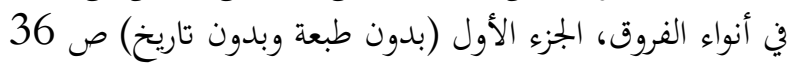

32

الجزء الثالث عشر، ص 522.

33 3ممد عميم الإحسان المجددي البركتي، التعريفات الفقهية، الجزء الأول (الطبعة الأولى، دار الكتب العلمية) 
البصيرة: مجلة الاراسات الإسلامية

AL-BASHIRAH: JOURNAL OF ISLAMIC STUDIES

Vol. 2 No. 2 (2020): 262-282

ISSN: $2807-2170$

Website: https://journal.stiba.ac.id

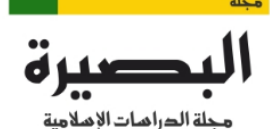

مجلة الصراهات الإصلامية

AL-BASHIRAH

2. القواعد المتفرعة عن القواعد الكبرى لكوها مختصة بابواب معينة من أبواب الفقه.

$$
\begin{aligned}
& \text { ت. القواعد الخاصة وهي القواعد المختصة بأبواب فقهية معينة. } \\
& \text { معنى القاعدة الأصل بقاء ما كان على ما كان }
\end{aligned}
$$

القاعدة الأصل بقاء ما كان على ما كان هي القاعدة المتفرعة و تندرج تحت القاعلى ماندة الكبرى

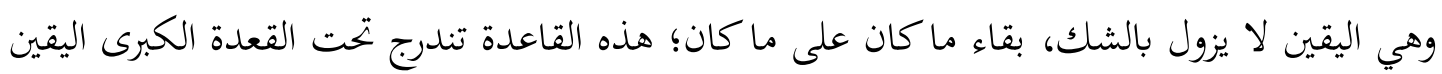
لا يزول بالشك، وأما المعنى فلها معنيان إفرادي وإجمالي.

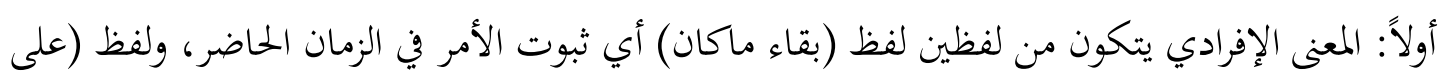

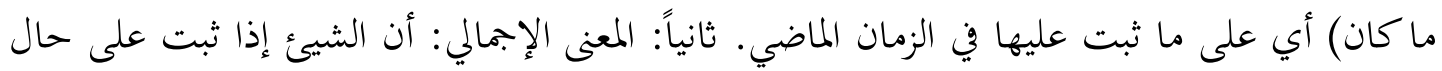

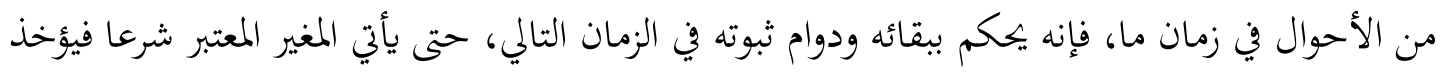

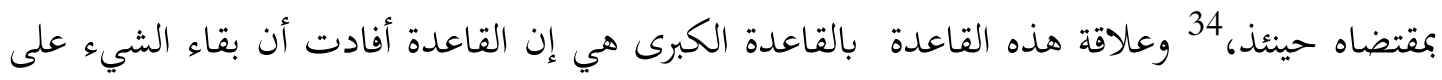

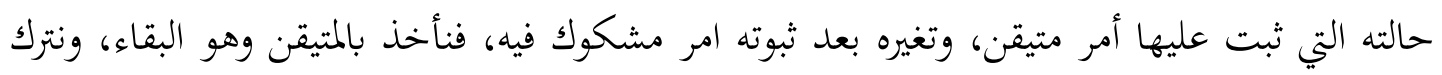
المشكوك فيه وهو التغير، وهذا ما تفيد القاعدة الكبرى.

حكم صوم فيمن أفطر ظنا غروب الشمس ثم تبين بعد ذلك خلافه عند المذاهب الأربعة

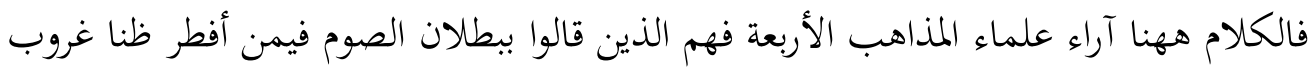
الشمس ثم تبين خلافه بعد ذلك مع أدلتهم، بما يلي:

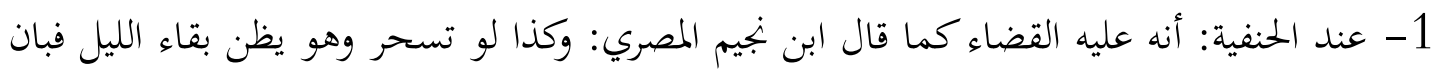

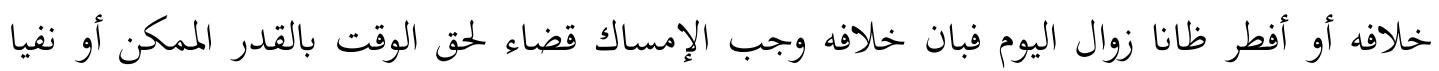

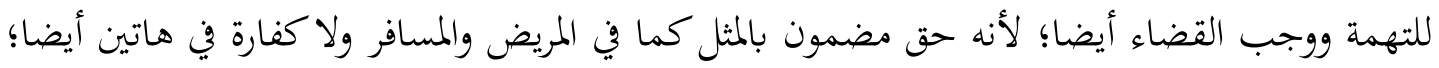

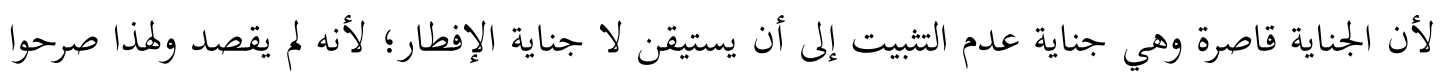

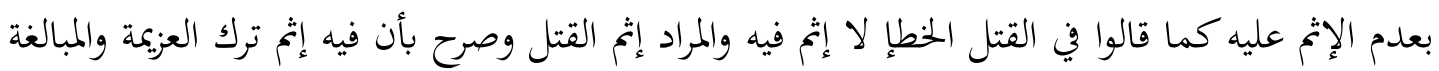

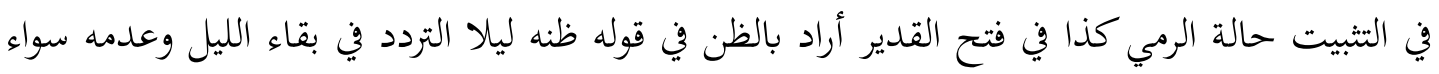

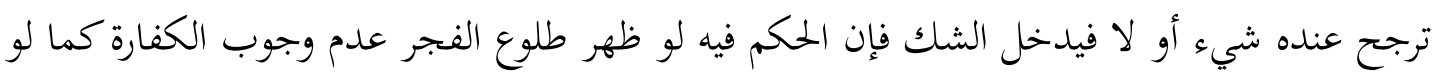

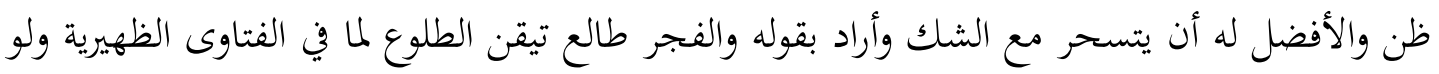

$$
35 \text { 35 مسلم بن محمد بن ماجد الدوسري، الممتع في القواعد الفقهية، ص124. }
$$


البصيرة: مجلة الداسات الإسلامية

AL-BASHIRAH: JOURNAL OF ISLAMIC STUDIES

Vol. 2 No. 2 (2020): 262-282

ISSN: $2807-2170$

Website: https://journal.stiba.ac.id

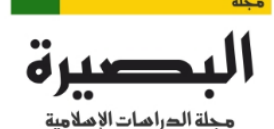

مجلة الصراهات الإصلامية

AL-BASHIRAH

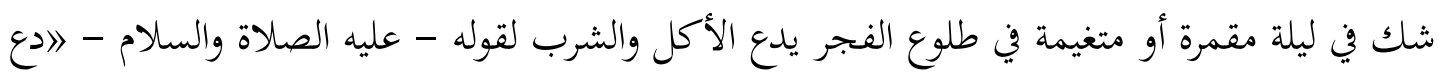

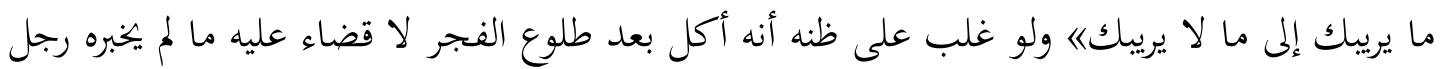

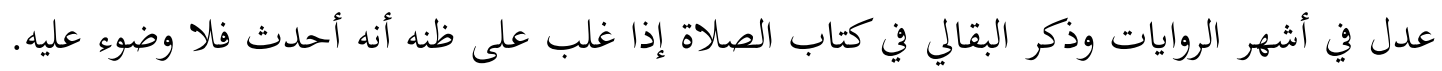

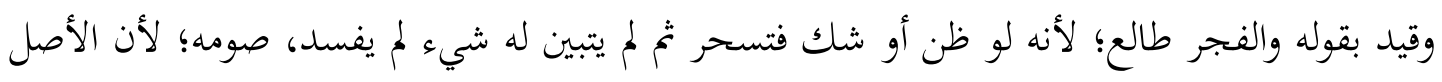

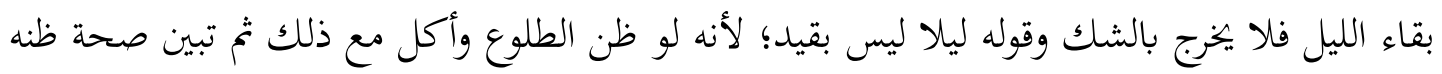

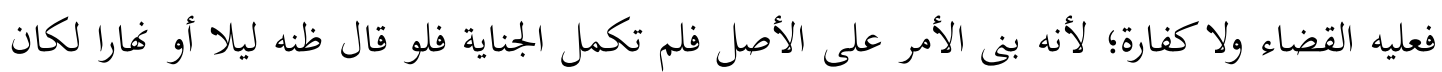

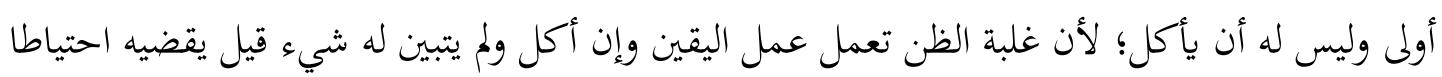

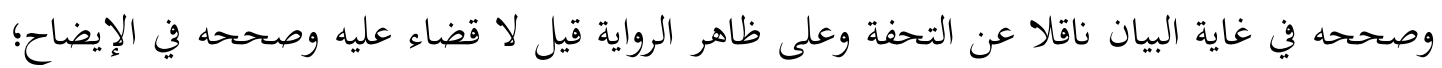

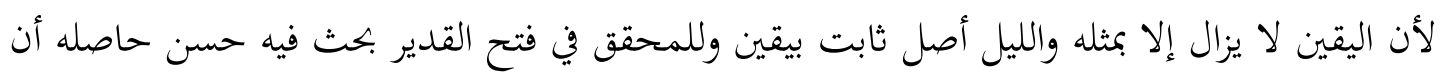

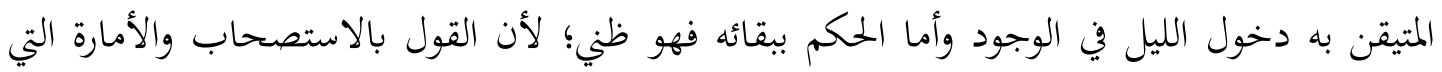

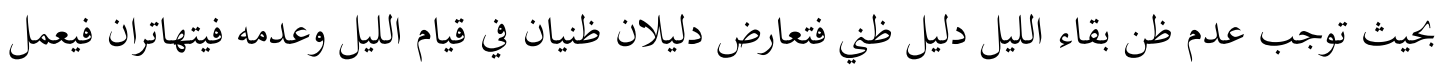

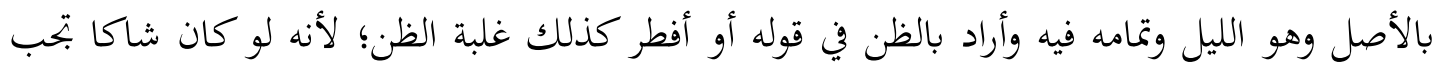

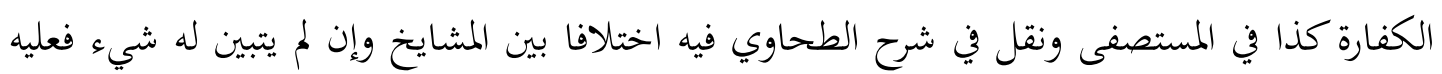

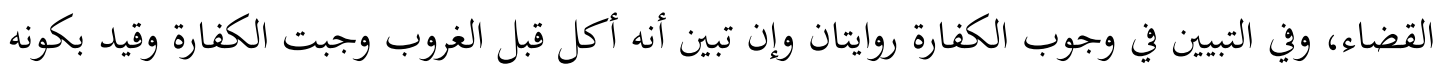

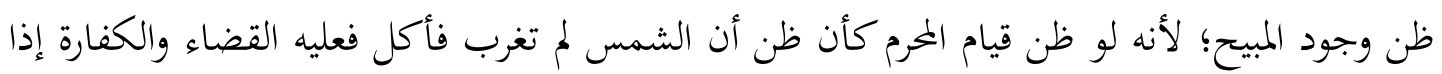

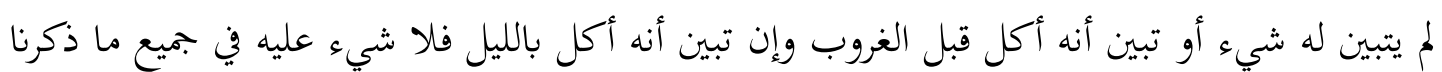

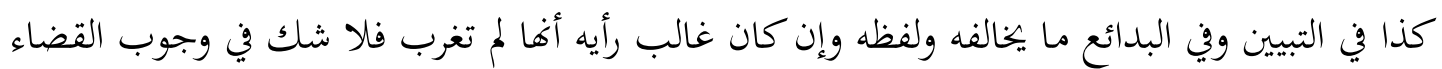

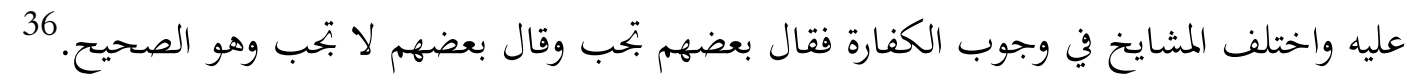

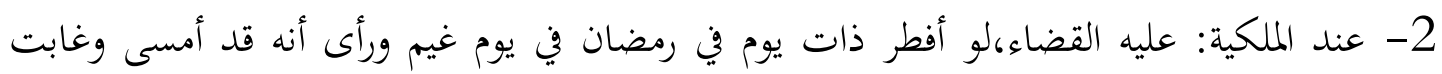

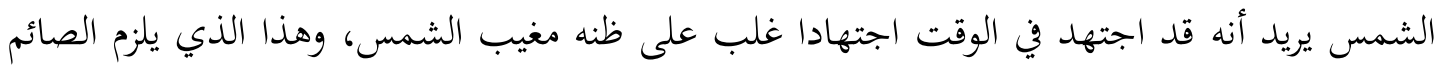

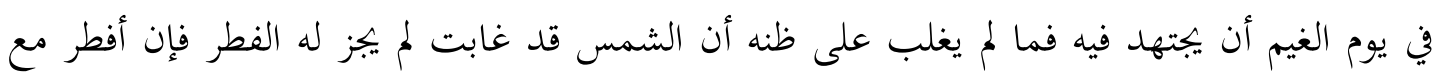

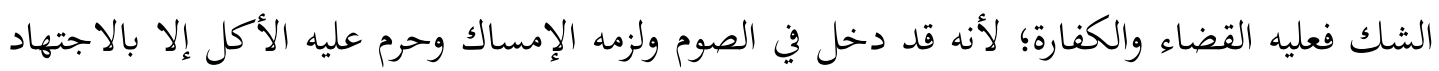

36 زين الدين بن إبراهيم بن محمد، المعروف بابن نجيم المصري، البحر الرائق شرح كنز الدقائق، الجزء الثاني (الطبعة الثانية دار الكتاب الإسلامي ، بدون تاريخ النشر) ص 314. 


\section{البصيرة: مجلة الاراسات الإسلامية \\ AL-BASHIRAH: JOURNAL OF ISLAMIC STUDIES \\ Vol. 2 No. 2 (2020): 262-282 \\ ISSN: $2807-2170$ \\ Website: https://journal.stiba.ac.id \\ •011 \\ مجلة الصراهات الإهلامية \\ AL-BASHIRAH}

وتيقن مغيب الشمس فإذا غلب على ظنه أن الشمس قد غابت حل له الفطر. 37 والدليل ما رواه مالك

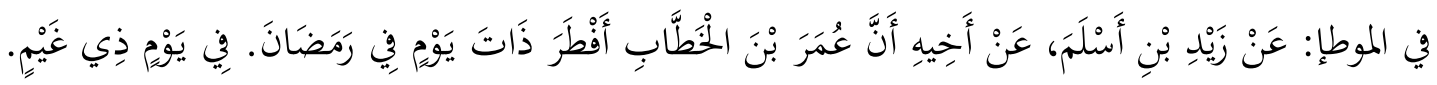

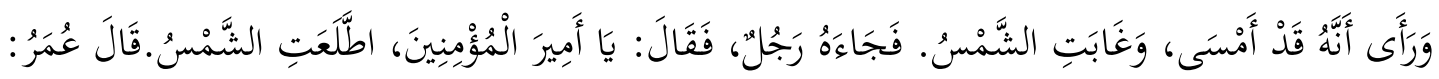

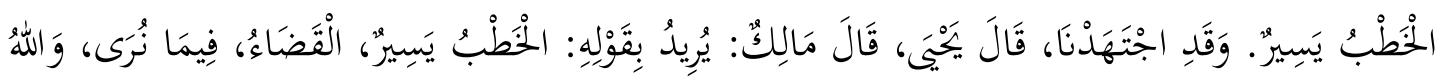

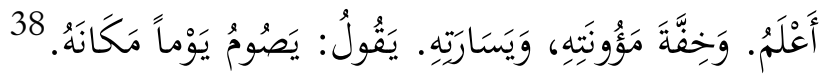
3- عند الشافعية: بطل صومه كما قال الخطيب في مغني المحتاج: والاحتياط أن لا يأكل آخر النهار إلا بيقين) كأن يعاين الغروب ليأمن الغلط (ويهل) الأكل آخره (بالاجتهاد) بورد أو غيره (في الأصح) كوقت الصلاة، والثاني: لا، لإمكان الصير إلى اليقين. أما بغير اجتهاد فلا يجوز ولو بظن؛ لأن الأصل بقاء النهار، وقياس اعتماد الاجتهاد جواز اعتماد خبر العدل بالغروب عن مشاهدة، وإن قال في البحر: إنه لا يجوز الفطر به كالشهادة على هلال شوال فهو قياس ما قالوه في القبلة والوقت والأذان (ويجوز إذا ظن بقاء الليل) بالاجتهاد؛ لأن الأصل بقاؤه (قلت: وكذا لو شك) فيه (و الله أعلم) لما ذكر، ولو أخبره عدل بطلوع الفجر لزمه الإمساك (ولو أكل باجتهاد أولا) أي أول النهار (أو آخرا) أي آخر النهار (وبان

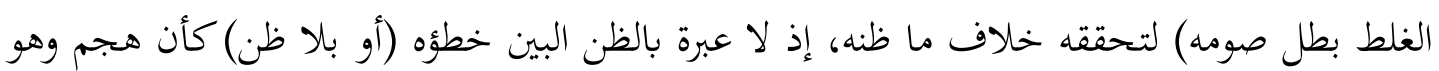
جائز في آخر الليل حرام في آخر النهار (ولم يبن الحال صح إن وقع) الأكل (في أوله) ؛ لأن الأصل بقاء الليل (وبطل) إن وقع الأكل (في آخره) ؛ لأن الأصل بقاء النهار. قال الشارح: ولا مبالاة بالتسمح في هذا الكلام لظهور المعنى المراد أي وهو أنه أدى اجتهاده إلى عدم طلوع الفجر فأكل، أو إلى غروب الشمس فأكل. 4- عند الحنابلة: لا يصح صومه فعليه القضاء، قال بن قدامة: أنه أكل مختارا ذاكرا للصوم، فأفطر، كما لو أكل يوم الشك، ولأنه جهل وقت الصيام فلم يعذر به، كالجهل بأول رمضان، ولأنه يمكن التحرز منه، فأشبه أكل العامد، وفارق الناسى؛ فإنه لا يمكن التحرز منه وأما الخبر، فرواه الأثرم، أن عمر قال:

37أبو الوليد سليمان بن خلف بن سعد بن أيوب بن وارث، المنتقى شرح الموطإ، الجزء الثاني (الطبعة الأولى،

مطبعة السعادة، 1332 هـ) ص 63. 38 مالك بن أنس بن مالك بن عال عامر الأصبحي المدني، الموطأ، الجزء الثالث (الطبعة الأولى، مؤسسة

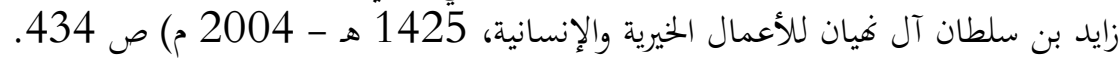

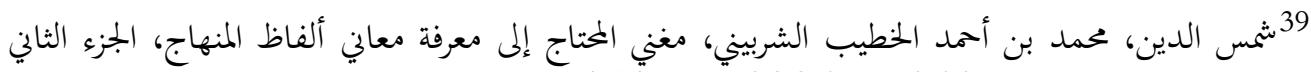

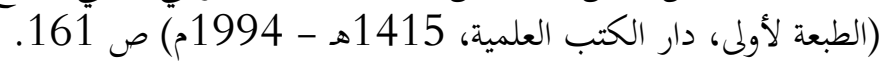




\section{البصيرة: مجلة الاراسات الإسلامية \\ AL-BASHIRAH: JOURNAL OF ISLAMIC STUDIES \\ Vol. 2 No. 2 (2020): 262-282 \\ ISSN: $2807-2170$ \\ Website: https://journal.stiba.ac.id

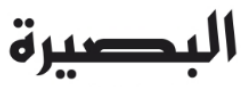 \\ مجلة الصراهات الإسلامية \\ AL-BASHIRAH}

من أكل فليقض يوما مكانه. 40 ما رواه البخاري بسنده (عَنْ أَسْمَاءَ بِنْتِ أَبِي بَكْرِ الصِّدِيقِقِ رَضِيَ اللَّهُ

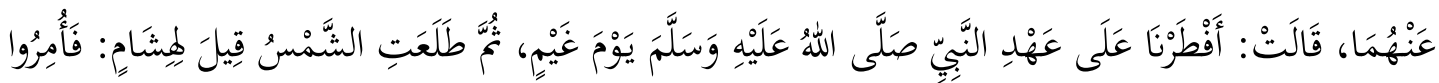

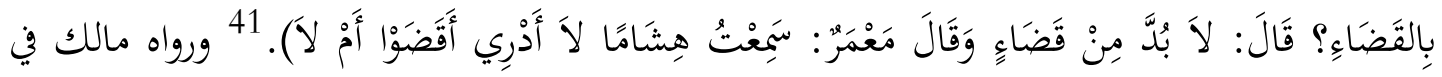

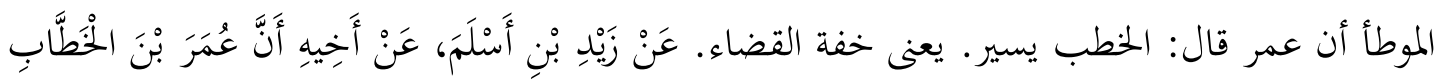

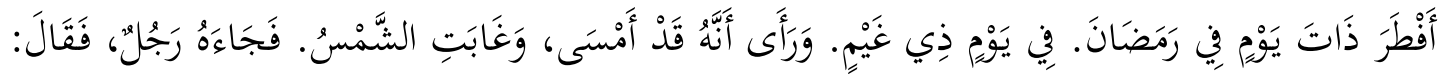

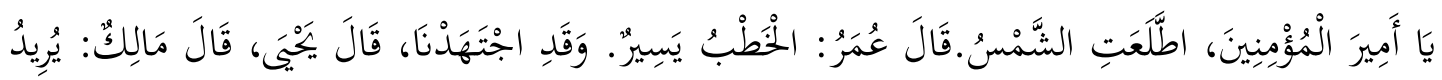

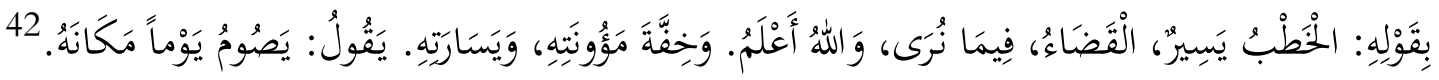
ثم قال ابن قدامة في كتابه المغني: وإن أكل يظن أن الفجر لم يطلع، وقد كان طلع، أو أفطر يظن أن الشمس قد غابت، ولم تغب، فعليه القضاء. لأنه أكل مختارا، ذاكرا للصوم، فأفطر، كما لو أكل يوم الشك، ولأنه جهل بوقت الصيام، فلم يعذر به، كالجهل بأول رمضان، ولأنه يمكن التحرز منه، فأشبه أكل العامد، وفارق الناسي، فإنه لا يمكن التحرز منه. 43

وأدلة هؤلاء الذين قالوا ببطلان الصوم فيمن أفطر ظنا غروب الشمس فبان خلافه بعد ذلك، بما يلي:

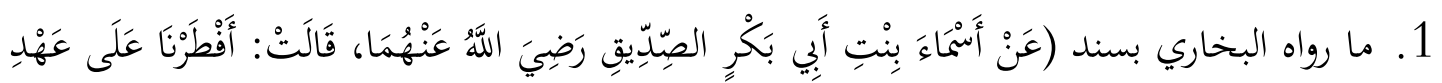

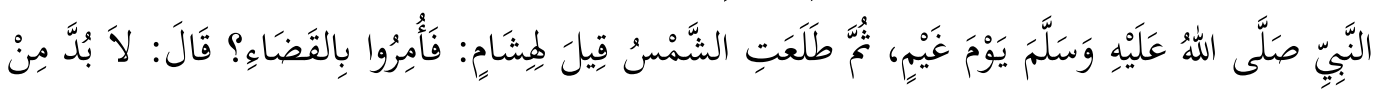

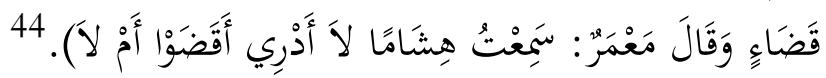

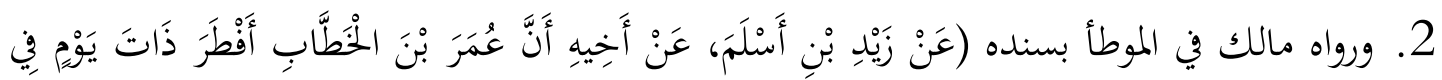

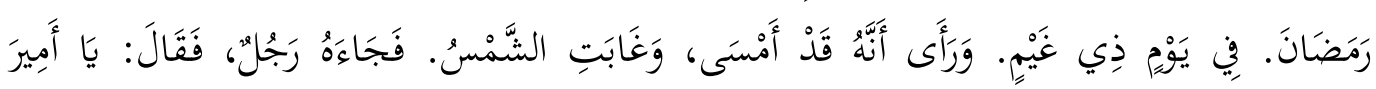

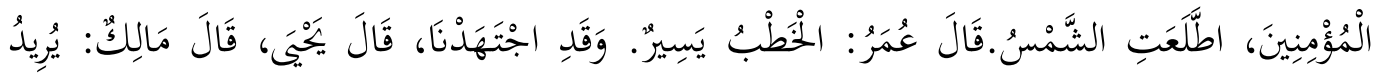

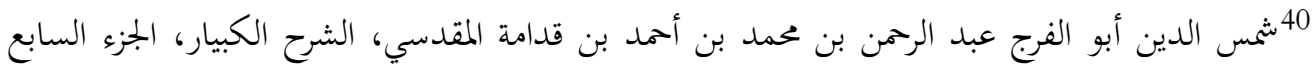

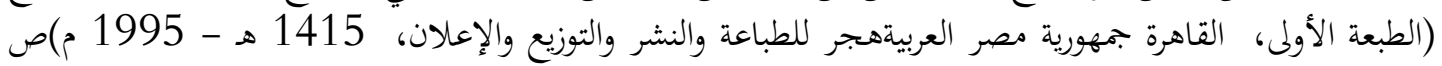

$$
\text { 41 41 4ممد بن إسماعيل أبو عبدالله البخاري الجعفي، صحيح البخاري، الجزء الثالث، ص } 36 .
$$

43 أبو محمد موفق الدين عبد الله بن أحمد بن محمد بن قدامة، المغني، الجزء الثالث (دون الطبعة والتاريخ،

مكتبة القاهرة) ص 147.

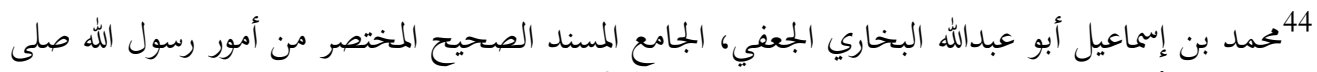

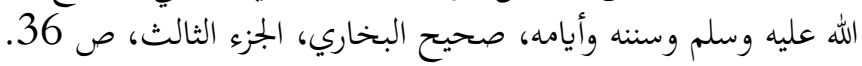




\section{البصيرة: مجلة الاراسات الإسلامية \\ AL-BASHIRAH: JOURNAL OF ISLAMIC STUDIES \\ Vol. 2 No. 2 (2020): 262-282 \\ ISSN: $2807-2170$ \\ Website: https://journal.stiba.ac.id

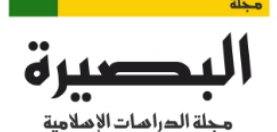 \\ مجلة الصراهات الإصلامية \\ AL-BASHIRAH}

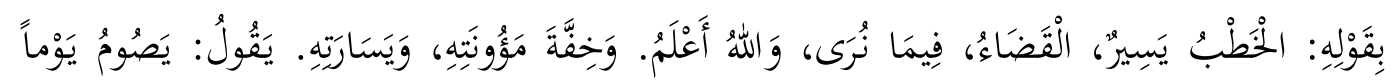
45 مَكَانَهُهُ

3. القاعدة الأصل بقاء ما كان على ما كان، أي بقاء النهار، فالعبرة هي بقاء النهار في هذه المسألة.

حكم صيام فيمن أفطر ظنا غروب الشمس ثم تبين بعد ذلك خلافه عند شيخ الإسلام ابن تيمية فالكلام هاهنا فيمن قال بصحة الصوم فيمن أفطر غروب الشمس ثم تبين خلافه بعد ذلك وهو

مذهب إسحاق ورواية عن أحمد وداود وابن حزم وعزاه إلى جمهور السلف، وبه قال المزبي من الشافعية، وهو اختيار شيخ الإسلام ابن تيمية. قال شيخ الإسلام ابن تيمية إجابةً للفريق الأول، بقوله هذا أن

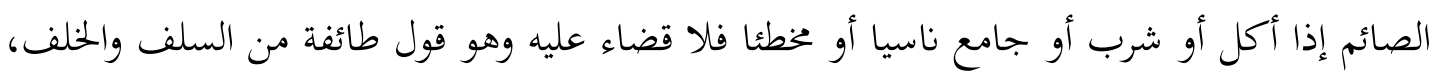
ومنهم من يفطر الناسي والمخطئ كمالك وقال أبو حنيفة: هذا هو القياس لكن خالفه لحديث أبي هريرة في الناسي ومنهم من قال لا يفطر الناسي ويفطر المخطئ وهو قول أبي حنيفة والشافعي وأحمد فأبو حنيفة جعل الناسي موضع استحسان وأما أصحاب الشافعي وأحمد فقالوا النسيان لا يفطر لأنه لا يمكن الاحتراز منه بخلاف الخطأ فإنه يمكنه أن لا يفطر حتى يتيقن غروب الشمس وأن يمسك إذا شك في طلوع الفجر. وهذا التفريق ضعيف والأمر بالكسس. فإن السنة للصائم أن يعجل الفطر ويؤخر السحور ومع الغيم المطبق لا يمكن اليقين الذي لا يقبل الشك إلا بعد أن يذهب وقت طويل جدا يفوت مع المغرب، ويفوت معه تعجيل الفطور والمصلي مأمور بصلاة المغرب وتعجيلها فإذا غلب على ظنه غروب الشمس أمر بتأخير المغرب إلى حد اليقين فربما يؤخرها حتى يغيب الشفق وهو لا يستيقن غروب الشمس وقد جاء عن إبراهيم النخعي وغيره من السلف وهو مذهب أبي حنيفة أفم كانوا يستحبون في الغيم تأخير المغرب وتعجيل العشاء و تأخير الظهر وتقديم العصر وقد نص على ذلك أحمد وغيره وقد علل ذلك بعض أصحابه بالاحتياط لدخول الوقت وليس كذلك؛ فإن هذا خلاف الاحتياط في وقت العصر والعشاء وإنما سن ذلك لأن هاتين الصلاتين يجمع بينهما العذر وحال الغيم حال عذر فأخرت الأولى من صلاتي الجمع وقدمت الثانية لمصلحتين. إحداهما التخفيف عن الناس حتى يصلوها مرة واحدة لأجل خوف المطر كالجمع بينهما مع المطر. والثانية أن يتيقن دخول وقت المغرب وكذلك يجمع بين الظهر والعصر على أظهر القولين وهو إحدى الروايتين عن أحمد ويجمع بينهما للوحل الشديد والريح الشديدة الباردة

45 4الك بن أنس بن مالك بن عامر الأصبحي المدني، الموطأ، الجزء الثالث، ص 434. 


\section{البصيرة: مجلة الاراسات الإسلامية \\ AL-BASHIRAH: JOURNAL OF ISLAMIC STUDIES \\ Vol. 2 No. 2 (2020): 262-282 \\ ISSN: $2807-2170$ \\ Website: https://journal.stiba.ac.id \\ | \\ مجلة الصراهات الإصلامية \\ AL-BASHIRAH}

ونحو ذلك في أظهر قولي العلماء وهو قول مالك وأظهر القولين في مذهب أحم، الثاني أن الخطأ في تقديم العصر والعشاء أولى من الخطأ في تقديم الظهر والمغرب فإن فعل هاتين قبل الوقت لا يجوز بحال بخلاف تينك فإنه يجوز فعلهما في وقت الظهر والمغرب لأن ذلك وقت لمما حال العذر وحال الاشتباه حال عذر فكان الجمع بين الصلاتين مع الاشتباه أولى من الصلاة مع الشك. وهذا فيه ما ذكره أصحاب المأخذ الأول من الاحتياط؛ لكنه احتياط مع تيقن الصلاة في الوقت المشترك ألا ترى أن الفجر لم يذكروا فيها هذا الاستحباب ولا في العشاء والعصر ولو كان لعلم خوف الصلاة قبل الوقت لطرد هذا في الفجر تم يطرد في العصر والعشاء. وقد جاء الحديث عن النبي صلى الله عليه وسلم بالتبكير بالعصر في يوم الغيم فقال: (بكروا بالصلاة في يوم الغيم فإنه من ترك صلاة العصر فقد حبط عمله). فإن قيل. فإذا كان يستحب أن يؤخر المغرب مع الغيم فكذلك يؤخر الفطور قيل: إنما يستحب تأخيرها مع تقديم العشاء بحيث يصليهما قبل مغيب الشفق فأما تأخيرها إلى أن يخاف مغيب الشفق فلا يستحب ولا يستحب ئب تأخير الفطور إلى هذه الغاية. ولذذاكان الجمع المشروع مع المطر هو جمع التقديم في وقت، المغرب ولا يستحب أن يؤخر بالناس المغرب إلى مغيب الشفق بل هذا حرج عظيم على الناس وإنما شرع الجمع لئلا يحرج المسلمون. وأيضا فليس التأخير والتقديم المستحب أن يفعلهما مقترنتين؛ بل أن يؤخر الظهر ويقدم العصر ولو كان بينهما فصل في الزمان. وكذلك في المغرب والعشاء بحيث يصلون الواحدة وينتظرون الأخرى لا يحتاجون إلى ذهاب إلى البيوت ثم رجوع وكذلك جواز الجمع لا يشترط له الموالاة في أصح القولين كما قد ذكرناه في غير هذا الموضع. وأيضا فقد ثبت في صحيح البخاري عن (أسماء بنت أبي بكر قالت: أفطرنا يوما من رمضان في غيم على عهد رسول الله صلى الله عليه وسلم ثم طلعت الشمس)، وهذا يدل على شيئين: على أنه لا يستحب مع الغيم التأخير إلى أن يتيقن الغروب؛ فإهم لم يفعلوا ذلك ولم يأمرهم به النبي صلى الله عليه وسلم والصحابة مع نبيهم أعلم وأطوع لله ولرسوله ممن جاء بعدهم. والثاني لا يجب القضاء فإن النبي صلى الله عليه وسلم لو أمرهم بالقضاء لشاع ذلك كما نقل فطرهم فلما لم ينقل ذلك دل على إنه لم يأمرهم به. فإن قيل: فقد قيل لهشام بن عروة: أمروا بالقضاء؟ قال: أو بد من القضاء، قيل: هشام قال ذلك برأيه لم يرو ذلك في الحديث ويدل على أنه لم يكن عنده بذلك علم: أن معمرا روى عنه قال: سمعت هشاما قال: لا أدري أقضوا أم لا؟ ذكر هذا وهذا عنه البخاري والحديث رواه عن أمه فاطمة بنت المنذر عن أسماء. وقد نقل هشام عن أبيه عروة أفم لم يؤمروا بالقضاء وعروة أعلم من ابنه وهذا قول إسحاق بن راهويه - وهو قرين أحمد بن حنبل ويوافقه في المذهب: أصوله وفروعه وقولما كثيرا ما يجمع بينه. والكوسج سأل مسائله لأحمد وإسحاق وكذلك حرب الكرماني سأل مسائله 
لأحمد وإسحاق وكذلك غيرهما؛ ولهذا يجمع الترمذي قول أحمد وإسحاق فإنه روى قولمما من مسائل

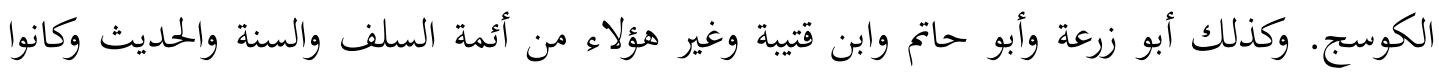

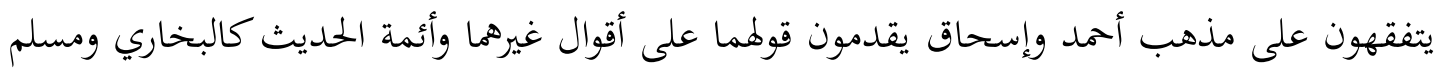

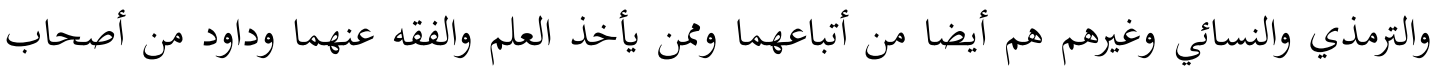

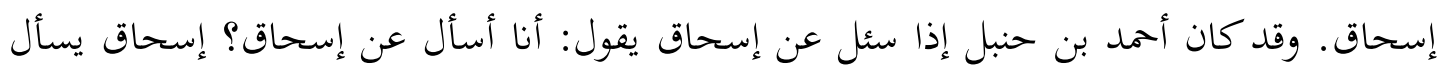

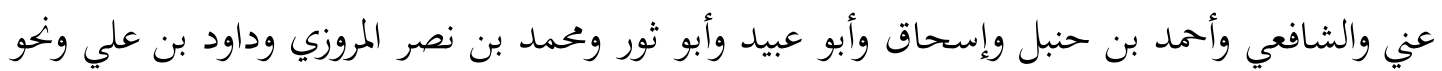

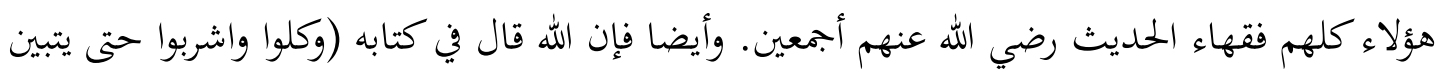
لكم الخيط الأبيض من الخيط الأسود من الفجر)، وهذه الآية مع الأحاديث الثابتة عن النبي صلى النهان الله

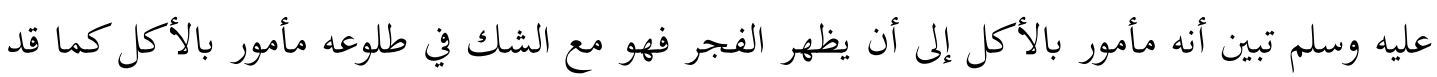
بسط في موضعه 46.

\section{تطبيق القاعدة في المسألة}

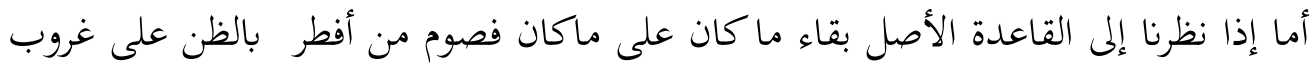

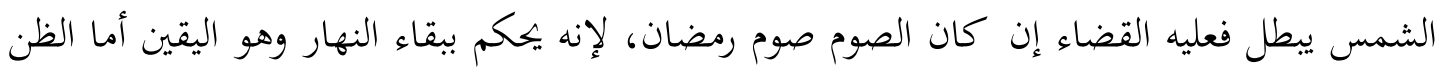

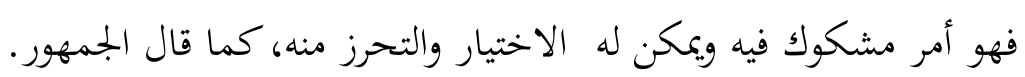

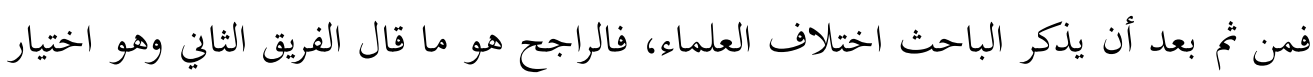
شيخ الإسلام ابن تيمية، للأسباب التالية:

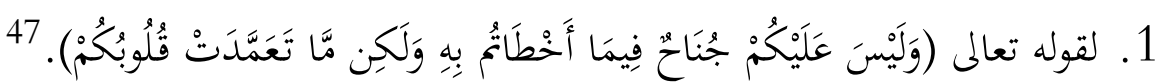

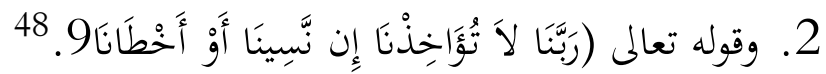

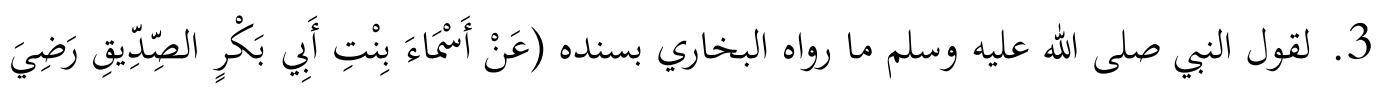

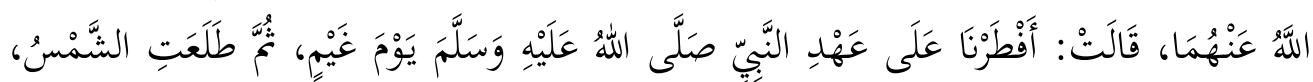

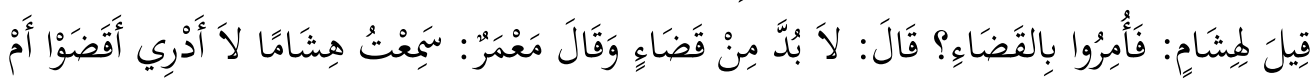

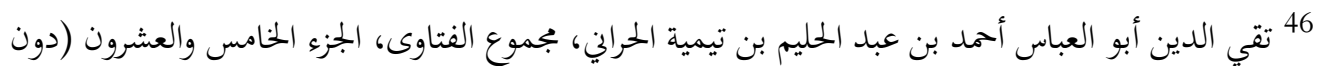

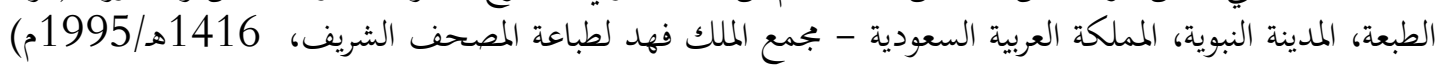

$$
\text { 47 سورة الأحزاب: الأية } 5 .
$$




\section{البصيرة: مجلة الار اسنات الإسلامية \\ AL-BASHIRAH: JOURNAL OF ISLAMIC STUDIES \\ Vol. 2 No. 2 (2020): 262-282 \\ ISSN: $2807-2170$ \\ Website: https://journal.stiba.ac.id

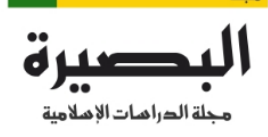 \\ AL-BASHIRAH

لاً). 49 فحديث أسماء لا يحفظ فيه إثبات القضاء ولا نفيه، وأما كلام هشام فقاله برأيه، ويدل عليه سؤال معمر له. فتحصَّل أفم لم يؤمروا بالقضاء، ولو كان عليهم قضاء لحفظ، فلما لم يحفظ عن النبي صلى الله عليه وسلم فالأصل براءة الذمة، وعدم القضاء. 50 هذا هو أصح الأقوال لموافقة الدليل ولكن الخروج من الخلاف أحوط إن أمكن ذلك، هو أن لن يقضي يوم الذي أفطر فيه على الظن.

الخاتمة

لما كان الصوم من أعظم العبادة الذي فرض الله تعالى على هذه الأمة بقوله تعالى (يَا أيَّهَها اللَّذِينَ

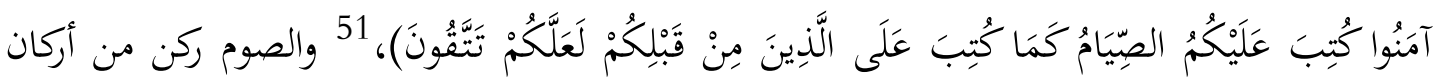
الإسلام لقول النبي صلى الله عليه وسلم ما رواه الإمام البخاري في صحيحه بسنده (عَنِ ابْنِ عُمَرَ، رَضِيَ

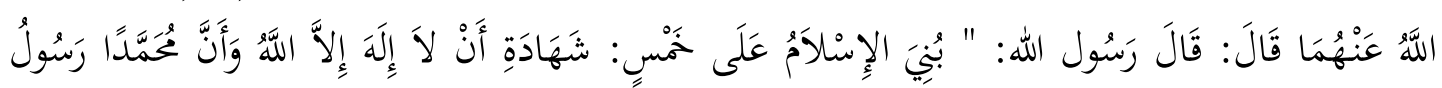

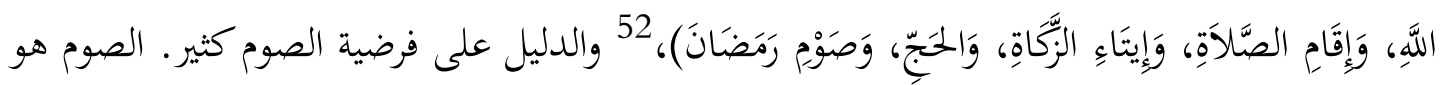

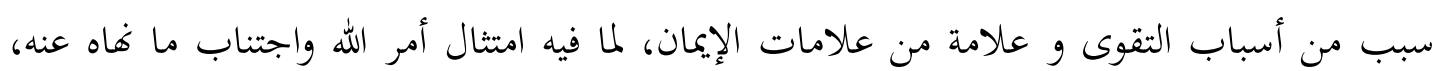
والصائم ترك كل م يبطل الصوم من الأكل والشرب والجماع، وفيه تسوية بين الأغنياء والمساكين، بين الأغنياء والضعفاء.

الصوم حق من حقوق الله على هذه الأمة فلا بد من حفظه واهتمام به وأدائه حق الأداء من الأحكام المتعلقة به، وأن في الصوم أموراً التي وجبت على المسلم أن يعرفها حتى يجتنب منها إن كانت منهياً عنها وأن يؤدي إن كانت فرضاً، وكذلك في الصوم أمور اتفق عليها العلماء وأمور اختلف فيها العلماء، وإن كانت الأمور متفقة عليها فعلينا أن نعمل بها بدون السؤال، أما إن كانت من الأمور المختلفة

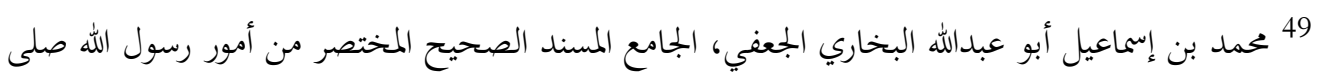

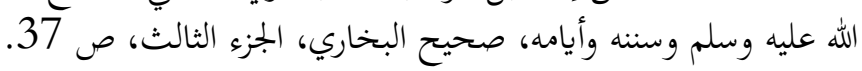

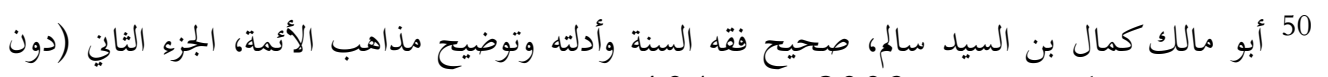

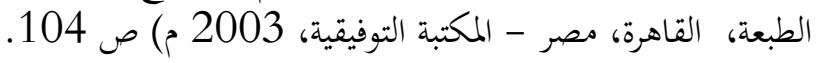

$$
51
$$

52

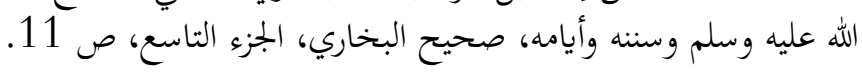




\section{البصيرة: مجلة الاراسات الإسلامية \\ AL-BASHIRAH: JOURNAL OF ISLAMIC STUDIES \\ Vol. 2 No. 2 (2020): 262-282 \\ ISSN: $2807-2170$ \\ Website: https://journal.stiba.ac.id

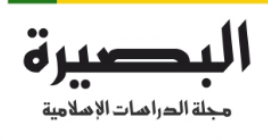 \\ AL-BASHIRAH

فيها العلماء فموقفنا في ذلك الأمور الرجوع إلى الكتاب والسنة لقول الله تعالى: (فَإِنْ تَنَازَعتمْم فِي شَيٍٍْ فُرُدوه إلى الله والرسول إن كنتم تؤمنون بالله واليوم اللأخر). 53 مثاله مسألتنا هذه.

فحكم الصوم عند الجمهور فيمن أفطر ظنا غروب الشمس ثم تبين خلافه فصومه باطل فعليه

القضاء، بأدلة عندهم، منها ما رواه البخاري بسنده ما رواه البخاري بسند (عَنْ أَسْمَاءَ بِنْتِ أَبِي بَكْرِ

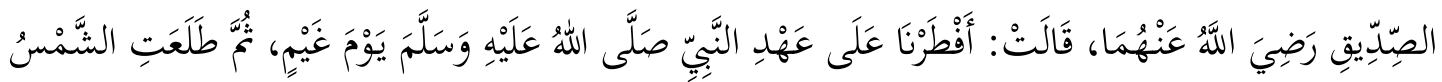

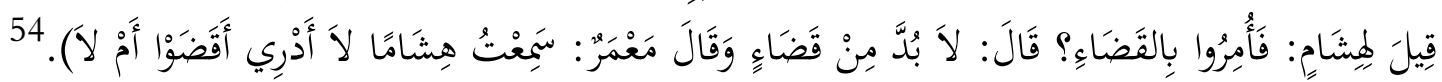
ورأى الجمهور وجوب القضاء ما قاله هشام لما سئل: لا بد من قضاء، والجمهور يدخل هذه الميألة تحت القاعدة الأصل بقاء ما كان على ماكان. بخلاف شيخ الإسلام ابن تيمية، أما عنده فصومه صحيح فلا عليه القضاء، بأدلة عنده منها الحديث السابق ورأى عدم وجوب القضاء لقول معمر سمعت هشام لاأدري أقضوا أم لا، وقال الشيخ للحديث السابق: لا يجب القضاء فإن النبي صلى الله عليه وسلم لو أمرهم بالقضاء لشاع ذلك كما نقل فطرهم فلما لم ينقل ذلك، دل على إنه لم يأمرهم به، ويفهم منكلام شيخ الإسلام ابن تيمة أن هذه المسألة خرجت أي لا تدخل تحت القاعدة الأصل بقاء ما كان على ما كان. ويرى الباحث أن الثاني هو الأرجح كما سبق ولكن كما قلنا أن الخروج من الخلاف أحوط إن أمكن ذلك، أي أن يقضي يوما الذي أفطر فيه على الظن.

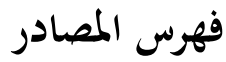

'Izzuddīn, Muhammad ibn Ismā'īl ibn Śalāḥ ibn Muḥammad al-Ḥusnā Abū Ibrāhīm. Subulussalām. t.cet; Dār al-Hadīẹ, t.t.

Abū al-Qāsim, Ismā'îl ibn 'Abbād ibn al-Abbās. Al-Muhịt fì Al-Lugah. Vol. II . t.cet. Al-'Ain̄̄, Abū Muḥammad Mạ̣mūd ibn Aḥmad ibn Mūsā ibn Aḥmad ibn Husain AlGaitānī Al-Ḥanafī Badru Al-Dīn. Al-Bināyah Syaraḥ Al-Hidāyah. Vol. IV cet;I, Bairūt: Dār Al Kutub Al-Ilmiyyah, 2000.

Al-Būkhārī al- Ju'fī, Abdullāh Muḥammad ibn 'Ismāīl ibn Ibrāhīm ibn Bardizbah. Śahih al-Bukhārī. t. tempat; Dār Ṭuruq al-Najāh, 1422H.

Al-Burkatī, Muhamamad 'Amīm al-Ihsān al-Mujaddadī. Al-Ta'rīfāt al-Fiqhiyyah. Vol. I, cet.I; Dār al-Kutub al-Ilmiyyah.

Al-Dausarī, Muslim ibn Muḥammad ibn Mājid. Al-Mumti' fi Qawā'id Al-Fiqhiyyah. Cet;I Riyāḍ: Dār al-Zadn̄̄, 2007.

$$
\begin{aligned}
& 53
\end{aligned}
$$

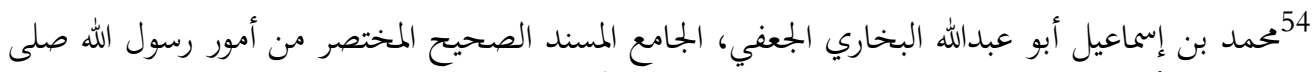

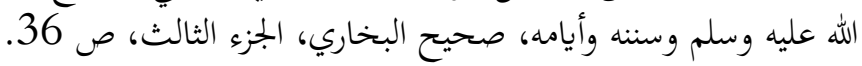$$
\text { شندري, محمد إحسان, أبي هندري, قاعدة ما كان على ماكان... }
$$ 


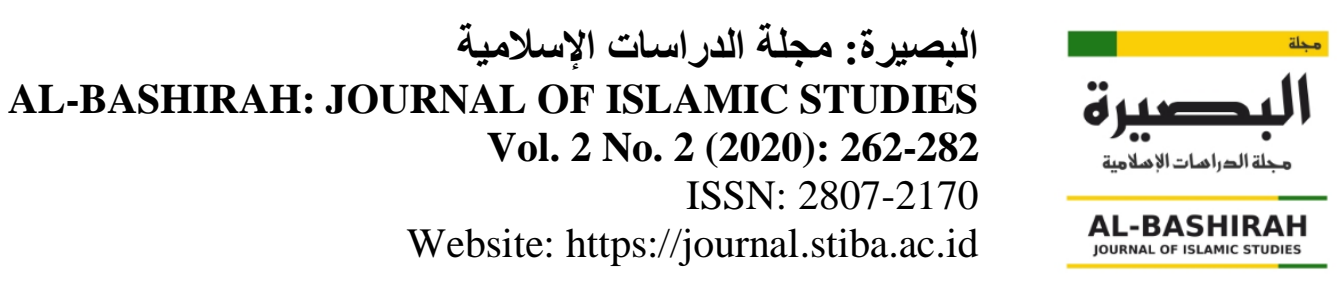

Al-Hanafī, Ayyūb ibn Mūsā al-Ḥusain̄̄ al-Quramī al-Kufawī Abū al-Baqā'. alKulliyāt Mu'jam Fī al-Muștalaḥ̄at wa al-Furūq al-Lugawiyyah. Vol.I, Bairūt: Muassasah al-Risālah. t.t.

Al-Jurjān̄̄, 'Alī ibn Muḥammad ibn 'Alī al-Zain al-Syarīf. Kitāb al-Ta'rîfāt. Vol.I, cet.I; Lubnān, Dār al-Kutub al-Ilmiyyah 1983.

Al-Madan̄̄, Mālik ibn Anas ibn Mālik ibn 'Āmir al-Aṣbaḥ̄. Al-Muwațta'. Vol.III, cet.I; Muassasah Zāyid ibn Sulțān Ālu Nahyān li A'māl al-Khairiyyah wa alInsāniyyah, 2004.

Al-Mahdawī, Abū al-Ṭāhir Ibrāhīm Abdu al-Ṡamad ibn Basȳ̄r al-Tanūkhī. AlBayyinah 'Alā Mabādi' Al-Taujīh. Vol. II cet; I, Bairūt: Dār ibn Ḥazm, 2007.

Al-Maqdis̄̄ Syamsuddīn Abū al-Farj Abdirramān ibn Muḥammad ibn Aḥmad ibn Qudāmah. Syarh al-Kibyār. Vol. IV, cet.I; al-Qāhirah, 1995.

Al-Maqdisī, Abū Muḥammad Muwaffaquddīn Abdullāh ibn Aḥmad ibn Muḥammad ibn Qudāmah. Al-Mugnī. Vol. III, t.cet; Maktabah al-Qāhirah. t,th.

Al-Qarāfī, Abū a-Abbās Syihābuddīn Aḥmad ibn Idrīs ibn Abdirraḥmān al-Mālik̄̄. Anwār al-Burūq fì Anwā al-Furūq. Vol. I, t.t; t.th.

Al-Subkī, Tājuddīn Abdul Wahhāb ibn Taqyuddīn. Isybāh wa al-Nażāir. Vol. I, cet.I; Dār al Kutub al-Ilmiyah 1411H.

Al-Syarbīnī, Syamsuddīn Muḥammad ibn Aḥmad al-Khațīb al-Syarbīnī. al-Iqnā' $f \grave{\imath}$ Halli Alfā̇̇ Abì Syujā'. Vol. I, t.cet; Bairūt; Dār al-Fikr.

Al-Ușaimīn, Muḥammad ibn Sāeleh. Syarah al-Arbā'in al-Nawāwī. Cet;I Al Qāhirah: Dār al-Ittibā'. 2014.

Al-Yaman̄i, Nisywān ibn Sa'̄̄d al-Humairī. Syamsul 'Ulūm wa Dawāu Kalām al'Arab min al-Kalūm. Vol.II, cet. Il; Bairūt: Dār al-Fikr al-Mu'àsir, 1999.

Al-Zujāj, Ibrāhīm ibn al-Sarī ibn Sahal Abū Ishạā. Ma'anī al-Qur'ān wa I'rābuhu. Vol.I, cet.I; Bairūt: 'Ālam al-Kutub, 1988.

Burhānuddīn, Ibrāhīm ibn Muḥammad ibn "Abdillāh ibn Muḥammad ibn Muflih Abū Isḥāq. Al-Mubdi' fì Syarh al-Muqni'. Vol. III, cet;I, Bairūt: Dār al-Kutub alIlmiyyah 1997.

Ibn Manżūr, Muhammad ibn Mukarram ibn 'Alī Abū al-Fadl. Lisān al-Arab. Vol. III, cet.III; Bairūt: Dār Șādir 1414H.

Ibn Nujaim al-Mis̀rī, Zainuddīn ibn Ibrāhīm ibn Muhammad. Al-Baḥr al-Rāiq Syarh Kanz al-Daqāiq. Vol.I, cet.II; Dār al-Kitāb al-Islāmī

Ibn Taimiyyah, Taqiyuddīn Abū al-'Abbās Ahmad ibn Abdil Ḥalīm. Majmū' Fatāwā. Vol. 25, t.cet; al-Madinah al-Munawwarah, 1995.

Ibn Wāriș, Abū al-Walīd Sulaimān ibn Khalaf ibn Sa'ad ibn Ayyūb. Al-Muntaqā Syarh al-Muwatta'. Vol.I, Matba'ah al-Sa'ādah 1332H.

Najmuddīn, Sulaimān ibn Abdil Qawī ibn al-Karīm al-Ṭufì al-Sarsaarī. Syarah Mukhtasar al-Raudah. Vol. I, cet.I; t.t, Muassasah al-Risālah 1987.

Novira, Nuraini. Ahkē̄m Șiyāmal-Muslimīn (Dirāsatul Muqāranah). Makassar: alMajallah al-Dirāsāt al-Islaāmiyyah. Vol. 2, No. 2 (2021). 85-106.

Rahạāl, A'lāuddīn Husain. Ma'ālim wa Dawābit al-Ijtihād 'Inda Ibn Taimiyyah, Malaiziyah: al-Jāmi' ah al-Islāmiyyah al-Ā'lamiyyah, 2000.

Sa' d̄̄, Abū Abdirraḥmān ibn Nāsìir ibn 'Abdillāh ibn Nāšir. Taisīr al-Karīm al-Raḥmān fì Tafsìr Kalām al-Mannān. Vol.I cet;II, Bairūt: Muassasah al-Risālah, 2015. 
البصيرة: مجلة الاراسات الإسلامية

AL-BASHIRAH: JOURNAL OF ISLAMIC STUDIES

Vol. 2 No. 2 (2020): 262-282

ISSN: $2807-2170$

Website: https://journal.stiba.ac.id

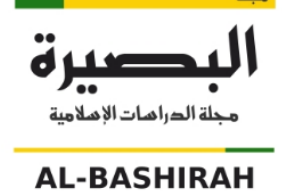

AL-BASHIRAH

JOURNAL OF ISLAMIC STUDIES

Sālim, Abū Mālik Kamāl ibn al-Sayyid. Șaḥ̄h Fiqh al-Sunnah wa Adillatuhu wa Taudīh Mażāhib al-Aimmah. Vol.II, t.cet; al-Qāhirah: 2003.

Tayyār, 'Abdullāh ibn Muhammad ibn Aḥmad. Wabalul Gamamah fì 'Umdatil Fiqh li ibn Qudāmah. Vol.I, cet.I; Riyāḍ: Dār al-Wațan lil Nasyr wa al-Tauzī’, $1429 \mathrm{H}$. 